\title{
Academic Freedom and Critical Speech in Hong Kong: China's Response to Occupy Central and the Future of "One Country, Two Systems".
}

\author{
Carole J.Petersen ${ }^{\dagger}$ and Alvin Y.H. Cheung ${ }^{\dagger \dagger}$
}

I. Introduction....

II. The "One Country, Two Systems" Model: Formal

Autonomy but with an Executive-Led System .....................8

III. Legal Protections for Academic Freedom and Critical

Speech in Hong Kong's Constitutional Framework .............13

IV. University Governance: The Impact of Increased

Centralization and Control

V. Conflicts between The Academic Community and the

Hong Kong and Central Governments .............................28

VI. Beijing's Retribution: Increased Interference in Hong

Kong Universities ..............................................................40

VII. The Disapearing Booksellers ..........................................53

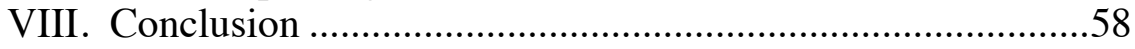

\footnotetext{
*Copyright (C) 2016 Carole J. Petersen and Alvin Y.H. Cheung. The authors thank the academics who agreed to be interviewed for this article and research assistants Jasmine Dave, Jason Jutz, and Jai Keep-Barnes for their assistance with research and editing. This is an updated version of a paper presented at a roundtable organized by the Council on Foreign Relations on December 15, 2015, and the authors thank the chair of the roundtable, Professor Jerome A. Cohen, and other participants for their comments. The William S. Richardson School of Law at the University of Hawai'i at Manoa supported Professor Petersen's travel to Hong Kong to conduct interviews for this article.

$\dagger$ Carole J. Petersen is a Professor at the William S. Richardson School of Law and Director of the Matsunaga Institute for Peace and Conflict Resolution, University of Hawai'i at Manoa. She taught law at the University of Hong Kong from 1991-2006 and at the City University of Hong Kong from 1989-1991.

$\dagger$ Alvin Y.H. Cheung is a JSD student at New York University School of Law, an affiliated researcher at the U.S.-Asia Law Institute at New York University School of Law, and a non-practicing member of the Hong Kong Bar.
} 


\section{Introduction}

Since July 1997, when Hong Kong was reunited with the People's Republic of China, academics in the Special Administrative Region of Hong Kong have fiercely protected their right to engage in critical speech and practice academic freedom. They have been aided by Hong Kong's regional constitution (known as the "Basic Law"), which incorporates international human rights treaties into domestic law and contains unusually detailed protections for freedom of expression, academic freedom, and educational autonomy. ${ }^{1}$ These constitutional provisions originated in the Sino-British Joint Declaration, a bilateral treaty that was duly registered with the United Nations. ${ }^{2}$ Nonetheless, this article documents a dramatic decline in academic freedom in Hong Kong since the last comprehensive study of the topic was published in 2006. ${ }^{3}$ This is partly because the Chinese Communist Party has made a concerted effort to punish Hong Kong academics and student organizations for their role in the Umbrella Movement and other pro-democracy movements. ${ }^{4}$ Equally important, there have been significant changes to the governance structure in Hong Kong's universities over the past decade, ${ }^{5}$ creating overlycentralized universities that are far too vulnerable to outside interference. These developments have already damaged the

1 See Xianggang Jiben Fa [Hong Kong Basic Law] (promulgated by Order No.26, Pres. of China, Apr. 4, 1990, effective July 1, 1997), arts. 27, 34, 39, 136-7 (1997) (H.K.) [hereinafter Basic Law] (although the Basic Law is a national law enacted by the National People's Congress of the People's Republic of China, it has the status of superior law in Hong Kong and is considered Hong Kong's constitutional instrument); Albert H.Y. Chen, The Interpretation of the Basic Law - Common Law and Mainland Chinese Perspectives, 30 H.K.L.J. 380-81 (2000); see discussion infra Part III (analyzing the legal protections for free speech, academic freedom, and educational autonomy and the role of the independent judiciary in preserving Hong Kong freedoms; and the role of academics and students in critiquing the controversial "national security" bill).

2 Joint Declaration of the Government of the United Kingdom of Great Britain and Northern Ireland and the Government of the People's Republic of China on the Question of Hong Kong, China-U.K., Dec. 19, 1984, 1399 U.N.T.S. 33 [hereinafter Joint Declaration].

3 Compare Part V-VIII, infra, with Jan Currie, Carole J. Petersen, \& Ka-Ho Mok, ACAdemic Freedom IN Hong Kong (Lexington Books, 2006) (documenting challenges but concluding that Hong Kong academics generally still enjoyed academic freedom) [hereinafter ACADEMIC FREEDOM].

\footnotetext{
4 See infra Part VI.

5 See infra Part IV.
} 
quality and international reputation of Hong Kong's universities, ${ }^{6}$ which will ultimately hurt not only Hong Kong but also the People's Republic of China.

A British colony from 1842-1997, Hong Kong was returned to China in 1997 under the "one county, two systems" model, which was devised by Deng Xiaoping and originally intended to provide a model for reunification with Taiwan. ${ }^{7}$ Public opinion polls demonstrated that the majority of Hong Kong residents would have preferred to remain British or to become an independent citystate. ${ }^{8} \quad$ Although colonial Hong Kong was inherently undemocratic, the British had provided a common law legal system and certain traditions that facilitated civil liberties, including an independent judiciary. ${ }^{9}$ In contrast, the rule of law was (and still is) seriously lacking in mainland China. ${ }^{10}$

In an effort to reassure the population, the Chinese and British governments made many promises in the Joint Declaration. The treaty provides that Hong Kong will maintain its common law legal system and independent judiciary and enjoy a "high degree of autonomy" as a Special Administrative Region of China ("SAR"). ${ }^{11}$ It also promises that Hong Kong residents will continue to enjoy freedom of expression and that the territory will maintain its pre-existing educational system, protect academic

6 See infra Part VI.

7 See, e.g., Ma Ying-jeou: 'One Country One System', Al JAZEERA (Sept. 29, 2014), http://www.aljazeera.com/programmes/talktojazeera/2014/09/ma-ying-jeou-aninexplicable-fear-201492613134516309.html [https://perma.cc/5Y72-97JX] (showing that while Taiwan is functioning as an independent nation, with its own military, it is highly unlikely that Taiwan would ever agree to unify with China under the "one country, two systems" model).

8 See Joseph Y.S. Cheng, Hong Kong in Search of a Future ch. 3 (Oxford Univ. Press 1984) (summarizing, among other surveys, a 1982 telephone survey reporting that $70 \%$ of respondents preferred to keep the status quo, $15 \%$ wanted Hong Kong to become a British "trust territory," and only $4 \%$ preferred that Hong Kong be returned to China).

9 See Carole J. Petersen, From British Colony to Special Administrative Region of China: Embracing Human Rights in Hong Kong, in HUMAN RightS IN ASIA: A Comparative Legal Study of Twelve Asian JuRisdictions, France, AND the United STATES (Randall Peerenboom, Carole J. Petersen \& Albert H.Y. Chen eds., Routledge 2006) [hereinafter Human RightS IN ASIA] (on Hong Kong).

10 See id.; Randall Peerenboom, Human Rights in China, in HumAn Rights IN ASIA, supra note 9 (on Mainland China).

11 Joint Declaration, supra note 2, IJ 3(2)-(3), Annex I, § III. 
freedom, and make its own educational policies. ${ }^{12}$ In addition, China agreed that the International Covenant on Civil and Political Rights (the "ICCPR"), which was applied to Hong Kong by the British government, would continue to apply to Hong Kong, although China has yet to ratify the treaty. ${ }^{13}$ Similar provisions were repeated in the Basic Law of the Hong Kong Special Administrative Region ("Basic Law"), Hong Kong's regional constitution. ${ }^{14}$ The question is whether these protections work in practice, even when the central government and its allies may have a strong incentive to curtail critical speech in Hong Kong.

In 2006, the first comprehensive study of academic freedom in Hong Kong concluded that academics had faced significant challenges since 1997, but that, on the whole, academic freedom was still very much alive. ${ }^{15}$ However, the study also reported that Hong Kong's universities were undergoing significant "management reforms," which were likely to leave the universities more centralized, less democratic, and thus more vulnerable to outside interference. ${ }^{16}$ This article demonstrates how, in the past decade, these changes have, indeed, made it far easier for the government and other external agents to influence decisionmaking processes in the universities. Meanwhile, relations between Hong Kong and Beijing have become increasingly tense

12 Id. I 3(5); id. Annex I, §§ X, XIII.

13 Id. Annex I, § XIII; see also United Nations Treaty Collection, Ch. IV (4), International Covenant on Civil and Political Rights (documenting that China has since signed the ICCPR, in 1998, but still has not ratified it and noting, at Endnote 6 to China, that the Covenant continued to apply to Hong Kong after China resumed exercising sovereignty over the territory),

https://treaties.un.org/pages/ViewDetails.aspx?src=TREATY\&mtdsg_no=IV-

$4 \&$ chapter=4\&clang=_en [https://perma.cc/92TD-Q8QT] (last visited June 6, 2016). China also agreed that the International Covenant on Economic, Social and Cultural Rights would continue to apply to Hong Kong, but that treaty has had less impact than the ICCPR. See Carole J. Petersen, Embracing Universal Standards? The Role of International Human Rights Treaties in Hong Kong's Constitutional Jurisprudence, in Interpreting Hong Kong's Basic Law: The Struggle for CoHerence (Fu Hualing, Lison Harris \& Simon N. M. Young eds., Palgrave Macmillan 2007) [hereinafter INTERPRETING HONG KONG's BASIC LAW].

14 Basic Law, supra note 1, arts. 27, 34, 39, 136-7.

15 ACADEMIC FREEDOM, supra note 3, at 145-55.

16 Id. at 153; see also Carole J. Petersen and Jan Currie, Higher Education Restructuring and Academic Freedom in Hong Kong, 6(5) POL'Y FUTURES IN EDUC. 589-98 (2008) (documenting further changes in the governance and management structures after 2006) [hereinafter Petersen \& Currie, Higher Education]. 
and pro-China forces have a greater incentive to interfere with academic freedom and critical speech. ${ }^{17}$ This is partly because Hong Kong residents have resisted proposals to introduce nationalism into the territory's public schools but also because democracy activists - many of whom are associated with Hong Kong universities-have become more confrontational, as demonstrated by Occupy Central and the student-led Umbrella Movement in 2014. ${ }^{18}$ Pro-Beijing forces have retaliated, directly targeting certain academics and publishers in Hong Kong. ${ }^{19}$ In light of these developments, it is clearly time to reassess academic freedom and educational autonomy in the territory.

Part II of the article begins by briefly summarizing the "one country, two systems" model, which provides extensive formal autonomy for the Hong Kong SAR but also places the reins of power primarily in the unelected executive branch. Part III then analyzes the legal protections for free speech, academic freedom, and educational autonomy and the role of the independent judiciary in preserving Hong Kong's freedoms. It also analyzes the role of academics and students in critiquing the controversial "national security" bill, which was introduced in the local legislature in 2003 to implement Article 23 of the Basic Law but withdrawn after more than 500,000 people took to the streets..$^{20}$

Part IV of the article then shifts to the issue of university governance and its relationship to academic freedom. It begins by briefly summarizing the "Robert Chung affair," a covert attempt to restrict academic research in the early years following China's resumption of sovereignty. ${ }^{21}$ This section demonstrates how the

17 See infra Part V.

18 Id. See also Elizabeth Barber \& Charlie Campbell, Pro-Democracy Students Storm Government Square in Hong Kong, TIME (Sept. 27, 2014).

19 See infra Part VI.

20 Article 23 obligates the local Hong Kong legislature to enact legislation "on its own" prohibiting, inter alia, sedition, subversion, secession, and theft of state secrets. For a general introduction to Article 23 and the failed attempt to enact legislation implementing it, see Carole J. Petersen, Hong Kong's Spring of Discontent: The Rise and Fall of the National Security Bill in 2003, in NATIONAL SECuRITY AND Fundamental Freedoms: Hong Kong's Article 23 Under Scrutiny ch. 1 (Fu Hualing, Carole J. Petersen \& Simon N.M. Young eds., H.K. Univ. Press 2005) [hereinafter NATIONAL SECURITY AND FundAMENTAL FREEDOMS].

21 See infra Part IV. See also Carole J. Petersen, Preserving Academic Freedom in Hong Kong: Lessons from the "Robert Chung Affair," 30 H.K.L.J. $165-76$ (2000) [hereinafter Petersen, Lessons]. 
Chief Executive's ties to the University of Hong Kong's Council weakened the Council's response to the interference. Subsequent changes to university governance have made Hong Kong's universities even more vulnerable to interference.

Part V then analyzes the escalating conflicts between the universities and pro-Beijing forces. While many academics have actively studied and critiqued Hong Kong's legal and political systems, some have moved beyond research and written advocacy and become activists in the human rights and democracy movements. ${ }^{22} \quad$ Student organizations have also become increasingly confrontational, reflecting their frustration with the slow pace of democratic reform. ${ }^{23}$ Meanwhile, mainland Chinese tourists have begun to take advantage of Hong Kong's free press and have obtained copies of publications that embarrass the Chinese Communist Party. ${ }^{24}$ All of these developments have increased the desire of the local and central governments to try to curtail critical speech in the territory. ${ }^{25}$

As demonstrated in Part VI, Beijing and its allies have, indeed, embarked upon an overt campaign to punish and intimidate its critics in Hong Kong. In 2015, the Council at the University of Hong Kong ("HKU") (which is now dominated by external members who are loyal to the government) refused to confirm the appointment of the former Dean of the Faculty of Law to a highlevel administrative position. ${ }^{26}$ Other academics have also reported that they believe they have been targeted for less favorable treatment, either because of their research and public commentary or because of their political activities as private citizens. $^{27}$

Part VII then analyzes the most egregious threat to freedom of

22 See infra Part V. See also Stephan Ortmann, The Umbrella Movement and Hong Kong's Protracted Democratization Process, 46 AsiAn AfF. 32 (2015).

23 See, e.g., Siegfried Sin, The Source of Hong Kong Youth's Frustration, S. CHINA MORNING POST (Dec. 12, 2014), http://www.scmp.com/comment/insightopinion/article/1661412/source-hong-kong-youths-frustration [https://perma.cc/6ZRU$752 \mathrm{~J}]$.

24 Chris Horton, In Hong Kong: A Sanctuary for Banned Books, ATLANTIC (Apr. 10, 2012), http://www.theatlantic.com/china/archive/2013/04/in-hong-kong-a-sanctuaryfor-banned-books/274831/ [https://perma.cc/LNF6-7WTM].

25 Id.

26 See infra Part VI.

27 Id. 
expression in Hong Kong to date-the disappearance of book publisher Lee Bo and his colleagues. All evidence indicates that Lee was abducted from Hong Kong by security agents of the central government, who have no legal authority to act within Hong Kong's borders but appear to have done so with impunity. ${ }^{28}$ Hong Kong residents were deeply shaken by the disappearances and the televised "confessions" of the booksellers while in the custody of mainland Chinese security forces. ${ }^{29}$ The message is clear: a Hong Kong resident who publishes material that embarrasses the Chinese Communist Party is no longer safe from arrest. $^{30}$

Part VIII concludes by considering the possible responses to these dramatic developments. On one hand, interviews indicate that at least some academics plan to curtail certain projects during this sensitive time. ${ }^{31}$ Hong Kong book shops have also stopped selling certain books that are banned in the mainland, clear evidence of intimidation. ${ }^{32}$ On the other hand, a more assertive "localist" movement has also developed in Hong Kong, one that openly blames mainland China for a host of social and political problems. ${ }^{33}$ While peaceful advocacy is still the norm, a small minority of local residents have begun to express their frustrations more aggressively, as demonstrated in the "Fishball Riots" of

28 程翔 [Ching Cheong], 李波事件暴露中共非法辦案的慣技 [Lee Bo Incident Exposes CCP's Habit of Illegal Handling of Cases], INITIUM (Jan. 6, 2016), https://theinitium.com/article/20160106-opinion-chingcheong-cwbbookstore/ [https://perma.cc/HQ92-DM9C].

29 Hong Kong Bookseller Defies China by Leading Protest, AL-JAZEERA (June 18, 2016), http://www.aljazeera.com/news/2016/06/hong-kong-bookseller-defies-chinaleading-protest-160618145552341.html [https://perma.cc/WPD2-QFQ4].

30 Michael Forsythe \& Andrew Jacobs, In China, Books That Make Money, and Enemies, N.Y. TIMES (Feb. 4, 2016), http://www.nytimes.com/2016/02/07/business/international/in-china-books-that-makemoney-and-enemies.html [https://perma.cc/NP89-L9Y8].

31 See infra Part VIII.

32 Christy Leung and Oliver Chou, Hong Kong Book Stores Pull Titles Banned in Mainland China from Shelves as Mystery Over Missing Bookseller Deepens, S. CHINA MoRning POST (H.K.) (Jan. 6, 2016), http://www.scmp.com/news/hong-kong/educationcommunity/article/1898232/least-one-hong-kong-store-pulls-books-banned [https://perma.cc/C3EP-DFHM].

33 Owen Fung, Face of the Pro-Independence Hong Kong National Party: Students and 20-Somethings who Shun Outside Donors, S. ChINA Morning Post (Mar. 31, 2016), http://www .scmp.com/news/hong-kong/politics/article/1932336/face-pro-independencehong-kong-national-party-students-and [https://perma.cc/78P9-4V9Z]. 
February $2016 .{ }^{34}$ Unfortunately, such actions are likely to generate even more oppression from Beijing. We therefore conclude the article by recommending concrete changes to governance in Hong Kong's universities which are urgently necessary to strengthen educational autonomy and rebuild academic freedom. We also explore what the international community and foreign academic institutions can do to assist Hong Kong during these difficult times.

\section{The "One Country, Two Systems" Model: Formal Autonomy but with an Executive-Led System}

"The autonomies which have been given to Hong Kong under the Basic Law are unique in the world. Our autonomies surpass those which are available to provinces and states under many federal systems." ${ }^{35}$ In 2002, this is how Hong Kong's Secretary for Constitutional Affairs described the "one country, two systems" model. ${ }^{36}$ On one level, Secretary Lam was correct: Hong Kong exercises many powers that are not typically held by a state in a federation. For example, it issues its own travel documents, including a Hong Kong identity card and a Hong Kong passport, and applies its own immigration controls. ${ }^{37}$ The SAR also issues

34 See, e.g., Ned Levin, Hong Kong's Failed Democracy Protests Fed Riots Over Street Vendors, WALL ST. J. (Feb. 10, 2016), http://www.wsj.com/articles/how-hongkongs-democracy-protests-fed-riots-over-street-vendors-1455108266

[https://perma.cc/Q282-RWG5] (explaining that the riot started as an angry response to local police officers' efforts to shut down popular food stalls during Chinese New Year; however, it was openly supported by "localists," a group of frustrated Hong Kong citizens who are advocating, for the first time since 1997, aggressive protests against China's interference); Hong Kong's Mongkok Clashes: More Than Fishballs, BRIT. BROAdCAST. CORP. (Feb. 9, 2016), http://www.bbc.com/news/world-asia-china35529785 [https://perma.cc/LCF5-3ERD].

35 See Stephen Lam, H.K. Sec'y for Constitutional Affairs, at the Seminar on Legal Landscape of China After Accession to WTO (Sept. 7, 2002), http://www.info.gov.hk/gia/general/200209/07/0907233.htm [https://perma.cc/Z837FQRG] (last visited Dec. 19, 2015).

36 For the historical background of the "One Country, Two Systems" concept (which was originally designed by China to facilitate reunification with Taiwan), see Ming K. Chan, The Politics of Hong Kong's Imperfect Transition: Dimensions of the China Factor, in The Challenge of Hong Kong's Reintegration with China (Ming K. Chan ed., H.K. Univ. Press 1997); Yash Ghai, Hong Kong's New Constitutional Order: The Resumption of Chinese Sovereignty and The Basic LaW 1, 35-80 (H.K. Univ. Press, $2^{\text {nd }}$ ed. 1999) [hereinafter GHAI].

37 Basic Law, supra note 1, art. 154. 
its own currency (the Hong Kong dollar), formulates its own monetary policy, and has an entirely separate taxation system. ${ }^{38}$ Although vague on many important issues, the Basic Law is crystal clear when it comes to Hong Kong's financial independence, stating that local tax revenues "shall not be handed over to the Central People's Government" and that Beijing "shall not levy taxes" in the SAR. ${ }^{39}$ Hong Kong is also empowered to "conclude and implement agreements with foreign states and regions and relevant international organizations" in a variety of fields, including economics, trade, finance, monetary, shipping, and communications. ${ }^{40}$

In addition to these specific powers, Hong Kong is vested with general executive powers ${ }^{41}$ and general legislative powers. ${ }^{42}$ The only significant limitations are in the areas of defense and foreign affairs $^{43}$ and in certain other areas where the Basic Law expressly allocates an executive or legislative power to the central government (such as the power to appoint the Chief Executive and the power to amend the Basic Law). ${ }^{44}$ Hong Kong's Legislative

38 Id. arts. 110-11. It should be noted, however, that the Basic Law places certain restrictions on the nature of Hong Kong's monetary policy. For example, the "issue of Hong Kong currency must be backed by a 100 percent reserve fund," (art. 111) and the local government shall "safeguard the free flow of capital within, into and out" of Hong Kong and shall not apply foreign exchange control policies (art. 112). These restrictions are not, however, generally viewed as examples of intervention by Beijing but rather as reflecting the commitment to maintain Hong Kong's free market and capitalist system.

39 Id. arts. 106-7 (explaining that the Basic Law obligates the local government to pursue fiscally conservative policies; for example, it "shall follow the principle of keeping expenditure within the limits of revenues" and "avoid deficits"); see also id. art. 108 (explaining also that when enacting tax legislation it shall take "the low tax policy previously pursued in Hong Kong as reference").

$40 I d$. art. 151. For further information on Hong Kong's powers regarding external affairs, see id. arts. 150-57; GHAI, supra note 36, at 461-69.

41 Basic Law, supra note 1, art. 16 (stating that Hong Kong "shall be vested with executive power" and "shall, on its own, conduct the administrative affairs of the Region in accordance with the relevant provisions of this Law"). For more detailed provisions on the powers of the Chief Executive, see $i d$. arts. 43, 48-53. For provisions relating to the powers of the Executive Council (the closest thing to a cabinet in Hong Kong) and the Hong Kong government generally, see id. arts. 54-65.

$42 I d$. art. 17 (stating that Hong Kong "shall be vested with legislative power"). For additional provisions relating to legislative powers and the legislative process, see id. arts. 8, 17-18, 66-79.

43 See id. arts. 13-14.

44 Id. arts. $45,159$. 
Council enacts laws in virtually every other field that is relevant to local governance and no one stops to examine whether a newly proposed bill fits within some enumerated power granted to the local legislature. ${ }^{45}$ Local laws are reported to the Standing Committee of the NPC, which has the power to invalidate the law "if it is not in conformity with the provisions of [the Basic Law] regarding affairs within the responsibility of the Central Authorities or regarding the relationship between the Central Authorities and the Region." 46 This situation has, however, never arisen. If it were to occur, the Standing Committee may not amend the law but rather must simply return and thereby invalidate it. $^{47}$

In contrast to the broad and general powers allocated to the Hong Kong SAR, the Basic Law defines, rather narrowly, the areas in which the central authorities shall exercise executive or legislative power. ${ }^{48}$ Article 8 provides that the sources of law in Hong Kong shall be: the Basic Law; Hong Kong's pre-existing laws (including ordinances, common law and the rules of equity); and new ordinances enacted by the local legislature. ${ }^{49}$ National laws other than the Basic Law are not, therefore, a source of law for Hong Kong. If the central government wishes to make a national law apply in Hong Kong it must go through a special procedure set forth in Article 18 of the Basic Law, which involves seeking advice from the Committee for the Basic Law (a joint committee with members from both Hong Kong and Mainland China) and then adding the national law to Annex III of the Basic

45 Basic Law, supra note 1, arts. 17, 73.

46 Id. art. 17, I 3.

47 Id.

$48 I d$. art. 18.

49 Id. art. 8. See also Quanguo Renmin Daibiao Dahui Changwu Weiyuanhui Guanyu Genju Zhonghua Renmin Gengheguo Xianggang Tebie Xingzhengqu Jibenfa di Yibai Liushi Tiao Chuli Xianggang Yuan You Falu de Jueding (全國人民代表大會常務 委員會關於根據《中華人民共和國香港特別行政區基本法》第一百六十條處理香 港原有法律的決定) [Decision of the Standing Committee of the National People's Congress on the Treatment of the Laws Previously in Force in Hong Kong in Accordance with Article 160 of the Basic Law of the Hong Kong Special Administrative Region of the People's Republic of China] Standing Comm. Nat'l People's Cong. (Feb. 23, 1997) [hereinafter 1997 Decision] (showing that laws already in force in the British territory of Hong Kong on June 30, 1997 were adopted as part of the law of the Hong Kong SAR, provided that they had not been determined by the Standing Committee of the National People's Congress to be in conflict with the Basic Law). 
Law. ${ }^{50}$ Moreover, Annex III must be confined to laws relating to defence, foreign affairs, and other matters "outside the autonomy" of the Region. ${ }^{51}$ Although that final phrase is vague and could be abused, in practice very few national laws have been added to Annex III. ${ }^{52}$

It should be noted that Article 18 also gives the central government the power to apply other national laws to Hong Kong in times of war or turmoil which "endangers national unity or security and is beyond the control of the government" of the SAR. ${ }^{53}$ Until recently, Hong Kong has enjoyed a reputation for being a very stable and peaceful community and thus there seemed to be little chance of Beijing intervening on this ground. However, as discussed in Part VIII of this article, if civil unrest due to delayed democracy becomes violent or beyond the local government's control, there is a possibility that Beijing would use Article 18 as an excuse to apply more restrictive national laws in Hong Kong.

Despite the narrow scope of the central government's formal legislative powers, it is widely acknowledged that Beijing can influence law and policies in Hong Kong through its power to appoint the Chief Executive. ${ }^{54}$ Most local legislation is drafted and proposed by the executive branch. Hong Kong legislators can

50 See Basic Law, supra note 1, art. 18 (declaring that national laws "shall not be applied" in Hong Kong except for those contained in Annex III to the Basic Law and setting forth the procedure for adding a national law to Annex III).

51 Id.

52 Basic Law, supra note 1, Annex III. The Hong Kong government publishes a list of national laws on Annex III. See Basic Law Full Text, THE BASIC LAW http://www.basiclaw.gov.hk/en/basiclawtext/annex_3.html [https://perma.cc/Y4FWY4F8]. See also HKSAR v. Ng Kung Siu, [1999] 2 H.K.C.F.A.R. 442. Annex III includes the Nationality Law of the PRC, the Declaration of the Government of the PRC on the Territorial Sea, the Regulations of the PRC Concerning Diplomatic Privileges and Immunities, plus three laws relating to the national calendar and the national flag, anthem and emblem. The application of the law on the national flag, which prohibits flag desecration, was challenged but ultimately upheld. Id. I 39 (showing however, in the same case, Hong Kong's Court of Final Appeal took the opportunity to confirm that the ICCPR is incorporated into the Basic Law). For discussion of the significance of this holding, see Petersen, Embracing Universal Standards? The Role of International Human Rights Treaties in Hong Kong's Constitutional Jurisprudence, in INTERPRETING Hong KonG'S BASIC LAW, supra note 13, at 35-36.

53 Basic Law, supra note 1, art. 18.

54 Id. art. 45 (providing that the Chief Executive is to be "selected" by local elections or consultations and then appointed by the Central People's Government). 
block government bills (and they often do so); but they cannot introduce new laws of any significance without the Chief Executive's consent. ${ }^{55}$ Moreover, only thirty-five of the seventy legislators are currently elected from geographic constituencies. ${ }^{56}$ Of the remaining thirty-five, thirty are selected from professional and industry-based "functional constituencies," which are designed to ensure a significant number of pro-government legislators $;{ }^{57}$ the remaining five legislators are chosen by voters not registered to any of the functional constituencies that existed before $2012 .^{58}$

Thus, the high degree of autonomy promised in the Basic Law is chiefly exercised by the Chief Executive, who is primarily accountable to the Chinese government. ${ }^{59}$ As the relationship between the central authorities and the Chief Executive is largely hidden from public scrutiny, ${ }^{60}$ it is impossible to assess the extent to which Beijing uses this channel. However, most commentators would probably agree that the hand of Beijing is increasingly evident. This is not surprising - the delay in introducing elections has steadily decreased public support for the appointed Chief Executive, making whoever is appointed to that office increasingly reliant upon Beijing.

$55 I d$. art. 74 (prohibiting an individual legislator from introducing any bill that relates to public expenditure or political structure or the operation of government. It also requires an individual legislator to obtain the Chief Executive's consent before introducing any bill that relates to government policies).

56 See Legislative Council of the Hong Kong Special Administrative Region of the People's Republic of China, History of the Legislature: Overview and Composition - the Legislative Council Today, http://www.legco.gov.hk/general/english/intro/hist_lcoverview-and-composition.htm.

57 See Michael E. DeGolyer, The Challenges of Researching Functional Constituencies, in Hong Kong's Constitutional Debates ch. 9 (Johannes Chan \& Lison Harris eds., H.K.L.J. Ltd. 2005); SimON Young \& ANTHONY O.K. LAw, A Critical Introduction to Hong Kong's Functional Constituencies (Civic Exchange Ltd. July, 2004) (explaining that while some functional constituencies, such as the legal functional constituency, allow individuals to vote, others use corporate voting).

58 The system of functional constituencies is particularly significant because Annex I to the Basic Law requires that a bill or amendment proposed by an individual legislator must receive a majority of votes from both categories of legislators.

59 Basic Law, supra note 1, Annex I, I7, Annex II, IJ 3.

60 See id. 


\section{Legal Protections for Academic Freedom and Critical Speech in Hong Kong's Constitutional Framework}

The Hong Kong courts have the power to interpret the laws of Hong Kong and to judicially review local executive acts and legislation. The local judiciary also interprets the Basic Law in the context of litigation, and there is no appeal beyond Hong Kong's Court of Final Appeal. ${ }^{61}$ On the other hand, the National People's Congress Standing Committee ("NPCSC") can also issue "legislative interpretations" of the Basic Law, which the Hong Kong judiciary is required to follow. ${ }^{62}$ Moreover, Hong Kong's Court of Final Appeal is required to seek an interpretation from the NPCSC when it determines that there is a need to interpret provisions of the Basic Law relating to the central government's powers or the relationship between the two governments. ${ }^{63}$ As of October 2016, the NPCSC had exercised its power to interpret the Basic Law only four times and only once at the request of Hong Kong's Court of Final Appeal. ${ }^{64}$

Prior to 1991, the local judiciary's power of judicial review had little impact in Hong Kong because there was no domestic bill of rights and the colonial constitution (the Letters Patent and Royal Instructions) contained very few limitations on the colonial government or legislature. ${ }^{65}$ This changed as a direct result of the June 4, 1989 massacre in Beijing's Tiananmen Square. With more than one million Hong Kong residents (approximately $20 \%$ of the population at the time) protesting against the Chinese government,

$61 I d$. art. 82 (stating that the power of final adjudication is vested in the Hong Kong Court of Final Appeal).

62 Id. art. 158; see Yash Ghai, The Political Economy of Interpretation, in INTERPRETING HONG KONG's BASIC LAW, supra note 13, at 127-138 (showing the history of Article 158 and the damage that Beijing's power of interpretation has done to the framework of the Basic Law and "one country two systems").

63 Basic Law, supra note 1, art. 158.

64 The Hong Kong government publishes English translations of the NPCSC's interpretations of the Basic Law and related "decisions," describing them as "instruments" and treating them as equivalent to the text of the Basic Law: http://www.basiclaw.gov.hk/en/basiclawtext/index.html [https://perma.cc/F4LV-SY2R]. The four interpretations of the Basic Law are listed as Instruments 17, 18, 20, and 22. Only the interpretation referred to as "Instrument 22" was made at the behest of the Court of Final Appeal.

65 See GHAI, supra note 36, at 14-19, 25-26. 
Hong Kong's colonial government had an urgent need to rebuild public confidence. $^{66}$ It thus proposed that the International Covenant on Civil and Political Rights (the "ICCPR") be largely incorporated into Hong Kong's domestic law, through the enactment of the Bill of Rights Ordinance and a simultaneous amendment to the colonial constitution. ${ }^{67}$ Although the Chinese government threatened to repeal the Bill of Rights in 1997 (using its powers under Article 160 of the Basic Law), in the end it only removed a few preliminary provisions which had no impact in practice. $^{68}$ The incorporation of the ICCPR into Hong Kong's domestic legal system thus continued, after the handover, through both the Bill of Rights Ordinance and Article 39 of the Basic Law. ${ }^{69}$ Indeed, the Hong Kong judiciary has regularly enforced the ICCPR in litigation challenging local laws and government policies and the ICCPR has thus become a sort of "gold standard" in Hong Kong's constitutional framework. ${ }^{70}$

The Joint Declaration and the Basic Law also contain many additional provisions protecting civil liberties, academic freedom, and educational autonomy. For example, Article 27 of the Basic Law provides, inter alia, that Hong Kong residents shall have freedom of speech, of the press, and of publication. ${ }^{71}$ Article 34 protects the freedom to engage in academic research, literary and artistic creation, and other cultural activities. ${ }^{72}$ The Basic Law also contains two provisions that expressly address educational autonomy and academic freedom. Article 137 states that "[e]ducational institutions of all kinds may retain their autonomy

66 Norman Miners, The Government And Politics of Hong Kong 27 ( $5^{\text {th }}$ ed. 1991).

67 Hong Kong Bill of Rights Ordinance, (1991) Cap. 383 (H.K.) (showing that the Bill of Rights was largely copied from the ICCPR as applied to Hong Kong).

68 See 1997 Decision, supra note 49. For analysis of why this did not affect the application of the Bill of Rights, see Peter Wesley-Smith, Maintenance of the Bill of Rights, 27 H.K.L.J. 15 (1997).

69 Basic Law, supra note 1, art. 39.

70 Petersen, Embracing Universal Standards? The Role of International Human Rights Treaties in Hong Kong's Constitutional Jurisprudence, in INTERPRETING HONG KONG'S BASIC LAW, supra note 13 (analysing the Hong Kong courts' approach to the ICCPR and other international human rights treaties that apply to Hong Kong). See also cases discussed in Albert H.Y. Chen, The Rule of Law Under "One Country Two Systems: The Case of Hong Kong 1997-2010, 6 NAT'L TAIWAN U.L.REV. 269, 285-291 (2011).

71 Basic Law, supra note 1, art. 27.

72 Id. art. 34. 
and enjoy academic freedom." ${ }^{\text {73 }}$ It also expressly authorizes educational institutions to recruit international staff and to use foreign teaching materials. ${ }^{74}$ It further provides that schools run by religious organizations may "continue to provide religious education, including courses on religion" and that students "enjoy freedom of choice of educational institutions and freedom to pursue their education" outside of Hong Kong. ${ }^{75}$ Similarly, Article 136 provides that Hong Kong shall, "on its own, formulate policies on the development and improvement of education, including policies regarding the educational system and its administration, the language of instruction, the allocation of funds, the examination system, the system of academic awards, and the recognition of educational qualifications."76 Taken together, these provisions provide Hong Kong with an exceptionally high and detailed level of legal protection for critical speech, academic freedom, and educational autonomy.

Given Hong Kong's constitutional framework and the willingness of Hong Kong's judiciary to enforce civil liberties, it is unlikely that the local government would ever propose a law or adopt a policy that overtly restricts freedom of expression or academic freedom. The closest that Hong Kong has come to enacting restrictive legislation was the failed attempt to enact national security legislation in 2002-2003. ${ }^{77}$ Article 23 has always been one of the most controversial and sensitive provisions in the Basic Law. It states:

The Hong Kong Special Administrative Region shall enact laws on its own to prohibit any act of treason, secession, sedition, subversion against the Central People's Government, or theft of state secrets, to prohibit foreign political organizations or bodies from conducting political activities in the Region, and to prohibit political organizations or bodies of the Region from establishing

\footnotetext{
73 Id. art. 137.

74 See id.

$75 \mathrm{Id}$.

76 Id. art. 136.

77 For further discussion, see generally Petersen, Hong Kong's Spring of Discontent: The Rise and Fall of the National Security Bill in 2003, in NATIONAL SECURity AND Fundamental Freedoms, supra note 20. Other chapters in the same volume analyse the specific legislative proposals, relating to treason, sedition, subversion, secession, protection of state secrets, and proscription of organisations.
} 
ties with foreign political organizations or bodies. ${ }^{78}$

The reason that Article 23 still has not been implemented in Hong Kong through local legislation is that the historic antigovernment demonstration of July 1, 2003 forced Tung Chee-hwa (the Hong Kong SAR's first Chief Executive, who was appointed by the central government) to withdraw the National Security (Legislative Provisions) Bill 2003. ${ }^{79}$ The saga is a classic example of how an unelected government can become too dismissive of public opinion. The government's initial proposals, which were distributed in 2002, were not entirely unreasonable. ${ }^{80}$ In fact, some of the proposals would have liberalized draconian laws that had been left over from the colonial period and are probably now unenforceable, as they conflict with the ICCPR. ${ }^{81}$ Unfortunately, the government also included proposals that went beyond the strict requirements of Article 23 and created apprehension among Hong Kong academics and the general population. For example, the bill proposed to add new categories of "protected information" and also to broaden the scope of offenses relating to "unauthorized and damaging disclosure" of protected information. ${ }^{82}$ The bill also included a proposal that could have allowed the central government to play a role in the proscription of local organizations (those with links to organizations proscribed in Mainland China) on grounds of "national security." "83 The public's concerns were exacerbated when Hong Kong government officials revealed that

78 Basic Law, supra note 1, art. 23.

79 See Legislative Council of the Hong Kong Special Administrative Region of the People's Republic of China, Bills Committee on the National Security (Legislative Provisions) Bill, http://www.legco.gov.hk/yr02-03/english/bc/bc55/general/bc55.htm (publishing the bill as introduced in 2003 and the Legislative Council Brief and noting that the bill lapsed without being enacted).

80 See Proposals to Implement Article 23 of the Basic Law: A Consultation Document (H.K. Gov't, Sept. 2002).

81 See Fu Hualing, Past and Future Offences of Sedition in Hong Kong, in NATIONAL SECURITY AND FundAMENTAL FREEDOMS, supra note 20 (explaining that, for example, the government's proposals regarding sedition would have liberalised Hong Kong's law of sedition, which is no longer enforceable due to conflicts with the ICCPR).

82 See Johannes Chan, National Security and the Unauthorized and Damaging Disclosure of Protected Information, in NATIONAL SECURITY AND FUNDAMENTAL FREEDOMS, supra note 20.

83 See generally Lison Harris, Lilly Ma, and C.B. Fung, A Connecting Door: The Proscription of Local Organizations, in NATIONAL SECURITY AND FUNDAMENTAL FREEDOMS, supra note 20. 
they had consulted with central government authorities on the content of the proposed legislation. ${ }^{84}$

Hong Kong academics played a significant role in critiquingand ultimately defeating - the proposals to implement Article 23. ${ }^{85}$ A survey of 442 teachers conducted during the initial consultation period revealed that $75 \%$ opposed the government's proposals, citing concerns for academic freedom and their ability to conduct research. ${ }^{86}$

Academics also organized numerous forums on the proposals, submitted comments to the government and the Legislative Council, launched signature campaigns, and gave interviews to the press to raise public awareness. ${ }^{87}$ The University of Hong Kong Faculty of Law was particularly active: Professor Johannes Chan was one of the founding members of the "Article 23 Concern Group," 88 while the Faculty's Centre for Comparative and Public Law ("CCPL") adopted Article 23 as a major research project and organized an international conference to critique the legislative proposals. ${ }^{89}$ University students were also active opponents of Article 23, sometimes openly jeering the Secretary for Security when she tried to defend the proposals during campus forums. ${ }^{90}$ Perhaps most important, at the end of the official period of public consultation, a group of academics who specialized in the fields of

84 See Petersen, Hong Kong's Spring of Discontent: The Rise and Fall of the National Security Bill in 2003, in NATIONAL SECURITy AND Fundamental FreEdoms, supra note 20 , at 22-23.

85 S.H. May, Academics Plan United Front on Article 23, S. China Morning Post (H.K.), Oct. 30, 2002, at 2.

86 Linda Young, New Security Law Seen as Threat to Teaching, Research; Broadbased Academic Opposition Endorses Signature Campaign Against Grey Areas of Provisions in Article 23, S. ChinA Morning Post (H.K.), Nov. 16, 2002, at 3.

87 For details, see ACADEMIC FREEDOM, supra note 3, at 96-99.

88 The Article 23 Concern Group was mainly composed of lawyers but included professors of law. It produced pamphlets, in both Chinese and English, that explained the legislation in a way that non-lawyers could understand, which helped to raise public awareness of the dangers to civil liberties posed by the legislation.

89 See Centre for Comparative and Public Law, Research: Article 23 of the Basic Law, http://www.law.hku.hk/ccpl/research/projects/article23.html [https://perma.cc/W3RJARML] (detailing the 2002 conference and other submissions to the government on the Article 23 proposals).

90 Ambrose Leung \& Ng Kang-chung, Regina Ip Slugs it Out with Rowdy Forum, S. China Morning Post (Oct. 16, 2002), http://www.scmp.com/article/394549/reginaip-slugs-it-out-critics-rowdy-forum [https://perma.cc/LT36-BDYE]. 
statistics and public opinion sampling formed a Research Team to assess the large number of public submissions on the government's proposals. $^{91}$ The Research Team published a lengthy report disclosing its methodology and demonstrating how the government had understated the level of opposition to the proposed legislation. $^{92}$

Despite the rising public outcry, the Hong Kong government adopted an inflexible attitude, rejecting suggestions that it publish a "White Paper" (a draft of the bill) before formally introducing the legislation in the Legislative Council. ${ }^{93}$ It also demanded an accelerated schedule for scrutinizing the bill and made it clear that it wanted the bill passed by the summer of 2003. ${ }^{94}$ Although legislators in opposition parties drafted many amendments, the government declined to negotiate with them, apparently because government officials assumed that they could rely upon representatives of the functional constituencies and other progovernment legislators to defeat any proposed amendments in the Legislative Council. $^{95}$

The government's strategy was particularly unwise because Hong Kong was simultaneously suffering from Severe Acute Respiratory Syndrome ("SARS") in 2003, which was taking a heavy toll on the local economy and public confidence. ${ }^{96}$ An elected government probably would have adopted a more conciliatory attitude, agreed to slow down the legislative process, and accepted some additional amendments proposed by the elected legislators. Instead, the government announced its own, very

91 See Research Team on the Compendium of Submissions on Article 23 of the Basic Law, Doing Justice to Public Opinion in Public Consultations: What to Do and What NOT to Do: A Case Study of the Government's Consultation Exercise on Its Proposals to Implement Article 23 of the Basic Law (2002), https://www.hkupop.hku.hk/english/resources/bl23/bl23gp/report/ [https://perma.cc/JC6H-CXDT].

$92 I d$.

93 Petersen, Hong Kong's Spring of Discontent: The Rise and Fall of the National Security Bill in 2003, in NATIONAL SECURITY AND FundAMENTAL FREEDOMS, supra note 20 , at 31 .

94 Id. at 33.

95 Id a a 28-37 (detailing the government's mistakes during the consultation process).

96 Lee Shiu Hung, The SARS Epidemic in Hong Kong: What Lessons Have We Learned?, J. Royal SOC'y MEDICINE (Aug. 2003). 
limited amendments and pressed for a quick vote on the Bill. ${ }^{97}$ This created a crisis atmosphere and ultimately caused more than 500,000 people to join an anti-Article 23 protest march on July 1, 2003, the sixth anniversary of Hong Kong's return to China. ${ }^{98}$ The government and its supporters were shocked by the size of the march. ${ }^{99}$ The Liberal Party, a pro-business party that controlled eight functional constituency seats and normally supported the government, responded by asking the government to delay consideration of the Bill. ${ }^{100}$ When the government refused, the leader of the Liberal Party resigned from Tung Chee-hwa's Executive Council and withdrew his party's support. ${ }^{101}$ The Hong Kong government eventually had to withdraw the Bill altogether and two ministers resigned as a result of the crisis. ${ }^{102}$ Tung himself resigned in early 2005, more than two years before the end of his second term as Chief Executive-officially for health reasons, but in reality, because he had lost credibility with both Beijing and the Hong Kong public. ${ }^{103}$

On one level, the Hong Kong government's inability to implement Article 23 of the Basic Law was a victory for civil liberties and academic freedom. On the other hand, the saga prompted Beijing to reexamine its entire Hong Kong policy. ${ }^{104}$ Since 2003, the central government has become even more reluctant to permit democratic reforms and increasingly interventionist in matters that are formally within the city's autonomy under the Basic Law. ${ }^{105}$ As demonstrated in later

97 Petersen, Hong Kong's Spring of Discontent: The Rise and Fall of the National Security Bill in 2003, in NATIONAL SECURITY AND FundAMENTAL FREEDOMS, supra note 20 , at 46-49.

98 Huge Protest Fills HK Streets, CNN (July 2, 2003), http://edition.cnn.com/2003/WORLD/asiapcf/east/07/01/hk.protest/ [https://perma.cc/PR9Z-VDVD] [hereinafter HK Protest 2003].

99 Id.

100 Petersen, Hong Kong's Spring of Discontent: The Rise and Fall of the National Security Bill in 2003, in NATIONAL SECURITY AND Fundamental FreEdoms, supra note 20 , at 50 .

$101 \mathrm{Id}$. at 50.

102 Id. at 52.

103 ACADEMIC FREEDOM, supra note 3, at 104.

104 Petersen, Hong Kong's Spring of Discontent: The Rise and Fall of the National Security Bill in 2003, in NATIONAL SECURITY AND FundAMENTAL FREEDOMS, supra note 20 , at 57.

105 See infra Part VI. 
sections of this article, Beijing and pro-Beijing forces in Hong Kong have also become increasingly hostile towards academics who regularly engage in research and advocacy projects that are critical of government proposals or the lack of democratic reform in Hong Kong. ${ }^{106}$

\section{University Governance: The Impact of Increased Centralization and Control}

Each of Hong Kong's publicly funded institutions of higher education is established by a local ordinance, beginning with the University of Hong Kong in 1911. ${ }^{107}$ The territory followed the traditional British model and bestowed the title of "Chancellor" upon the Governor of Hong Kong. In the colonial period, that position was largely ceremonial and the Vice Chancellor (or President in some institutions) would be recognized as the highest ranking official and the person with true authority in the institution. ${ }^{108}$ The Chancellor did hold the power to appoint the University Council (which includes external as well as internal members). ${ }^{109}$ However, in the colonial era, this meant that a university submitted a list of suggested members who would then be formally appointed by the Governor, as Chancellor. ${ }^{110}$ This is not to suggest that the colonial government paid no attention to university politics, ${ }^{111}$ but the colonial government generally

\footnotetext{
106 See infra Parts VI-VIII.

107 See, e.g., University of Hong Kong Ordinance, (1911) Cap. 1053, (H.K.) (setting goals for the establishment of a university).

108 Alex Lo, Chief Executive as Chancellor of Hong Kong's Universities is an Anachronism, S. CHINA Morning Post (H.K.) (July 13, 2015), http://www.scmp.com/comment/insight-opinion/article/1838191/chief-executivechancellor-hong-kong-universities [https://perma.cc/QBT4-KZRJ].

109 Id.

110 Cannix Yau, Politics has Always Played a Role in University of Hong Kong's Complex 104-Year History, S. ChInA MoRning Post (H.K.) (Sept. 12, 2015), http://www.scmp.com/news/hong-kong/education-community/article/1857420/politicshas-always-played-role-university-hong [https://perma.cc/3H49-E7KU] (quoting Professor Peter Cunich, an historian who has published a history of the University of Hong Kong).

111 Id. (noting that the colonial government did monitor the University of Hong Kong for signs of student radicalization and that at least one lecturer was compelled to take early retirement due to his pro-communist views, which Professor Cunich described as a "blotch" on the record of the University of Hong Kong).
} 
exercised a "laissez-faire" approach. ${ }^{112}$ Over time, the number of degree-granting institutions increased and the University Grants Committee was established to make recommendations on funding and to serve as a "buffer" between the government and publicly funded institutions of higher education. ${ }^{113}$

In 1997, the Governor was replaced by the first Chief Executive, Tung Chee-hwa, who inherited the title of "Chancellor" for all eight publicly funded degree-granting institutions. ${ }^{114}$ In hindsight, this automatic continuation of the tradition was a mistake, as there is evidence that the position is being used far more than during the colonial period to influence the public universities. ${ }^{115}$ For example, rather than allowing each university to suggest a list of council members, the Chief Executive now appoints anyone he wants to university councils, with little regard for the institution's preferences or need for expertise. ${ }^{116}$ Moreover, Hong Kong's Chief Executives are now more likely than colonial Governors to use their influence to overtly interfere in university business. ${ }^{117}$

In order to illustrate the effect of these changes, this section of the article will first briefly review the "Robert Chung" incident in 1999-2000, as it is still the most famous post-1997 attempt by the Hong Kong government to directly restrict an academic's

112 Id. (quoting Professor Peter Cunich and Elizabeth Wong, who served as Secretary for Health during the colonial period).

113 See Carlson Tong, Chairman, University Grants Committee, Message from the Chairman of the UGC, http://ugc.hk/eng/ugc/about/message/chairman.htm [https://perma.cc/64CH-DBTY] (last visited Mar. 15, 2016).

114 The eight institutions are: the University of Hong Kong; Chinese University of Hong Kong; Hong Kong University of Science and Technology; Hong Kong Polytechnic University; City University of Hong Kong; Hong Kong Baptist University; Lingnan University; and the Education University of Hong Kong, previously known as the Hong Kong Institute of Education.

115 See Yau, supra note 110.

116 University Grants Committee, Governance in UCG-funded Higher Education Institutions in Hong Kong, (submitted to the UGC by Sir Edward Newby in September 2015 and published by the UGC on Mar. 30, 2016), at 20, http://www.ugc.edu.hk/eng/ugc/publication/report/her/her.htm [https://perma.cc/JS5JZJ3A] (last visited Apr. 10, 2016) [hereinafter Newby Report]; see Yau, supra note 110 (noting the similar observations by Professor Cunich when interviewed by the S. China Morning Post).

117 See $i d$. 
research. ${ }^{118}$ In 1999, Robert Chung Ting-yiu was a PhD candidate at the University of Hong Kong ("HKU"). ${ }^{119}$ He developed an opinion poll research project that tracked the declining popularity of Tung Chee-hwa. ${ }^{120}$ In July 2000 (after he had completed his $\mathrm{PhD}$ and secured a position at HKU), Chung published a short article alleging that he had been pressured to discontinue the project in the previous year. ${ }^{121}$ He claimed that "more than once, I was given a clear message from Mr. Tung via a special channel that my polling activities were not welcomed. Mr. Tung did not like me polling his popularity or the Government's credibility. I was told that he did not like to see universities involved in such activities and that our polls should stop." 122

The article generated a good deal of controversy and the government initially responded by demanding that Chung identify the "special channel" who had allegedly pressured him. ${ }^{23}$ Chung eventually revealed that the Vice-Chancellor (HKU's highestranking officer) had sent him the message, via Professor Wong Siu Lun (a Pro-Vice-Chancellor and Robert Chung's PhD supervisor). ${ }^{124}$ The Vice-Chancellor responded swiftly to the allegation: although he admitted that Andrew Lo, a "Senior Special Assistant" to Tung Chee-hwa, had visited him at HKU to discuss Robert Chung's research project, the Vice Chancellor insisted that he had never asked anyone at HKU to put pressure on Robert Chung. ${ }^{125}$ As this created a dispute of fact, HKU's Council had little choice but to appoint an Independent Investigation Panel, consisting of a former judge of the High Court, a senior barrister,

\footnotetext{
118 For a summary of the Robert Chung affair, see Petersen, Lessons, supra note 21.

119 Id.

120 Id.

121 Id.

122 Robert Chung, Pressure to Stop Opinion Polls not Welcome, S. ChInA Morning Post (H.K.), July 7, 2000, at 1.

123 Exco Three Turn Up Heat on Pollster, S. China MoRning Post (H.K.), July 12,

124 Pollster "Irresponsible" if he Withholds Source: Renewed Calls for Clarification Turns Up Heat on Pollster, S. China Morning Post (H.K.), July 13, 2000, at 2.

125 See Mark Lander, Citing Pressure, A Pollster Says Academic Freedom is Under Siege in Hong Kong, N.Y. TimeS (July 16, 2000), http://www .nytimes.com/2000/07/16/world/citing-pressure-a-pollster-says-academicfreedom-is-under-siege-in-hong-kong.html [https://perma.cc/99ZE-PM6N].
} 2000 , at 7 . 
and the Executive Officer of Hong Kong's Consumer Council. ${ }^{126}$ The Panel held public hearings, which were televised and widely reported in the press. ${ }^{127}$ Given the seriousness of the allegations, the Panel also decided that it would adopt the criminal standard of proof-beyond a reasonable doubt-when assessing the allegations made by Robert Chung. ${ }^{128}$

After more than two weeks of hearings, the Panel delivered its Report to HKU's Council. ${ }^{129}$ The Panel determined that Robert Chung's allegations were true: Professor Wong (acting at the behest of the Vice-Chancellor) had conveyed a message to Robert Chung that was "calculated to inhibit his right to academic freedom." 130 The Panel concluded that this action was taken as a result of the meeting between the Vice-Chancellor and Andrew Lo, a special assistant to Tung Chee-hwa. ${ }^{131}$ The Panel also concluded that the Vice Chancellor and Andrew Lo had not given full and accurate testimony regarding their initial meeting to discuss Robert Chung's research. ${ }^{132}$ Government lawyers representing $\mathrm{Mr}$. Lo reacted strongly to this finding and initially requested the Council to delay releasing the Report to the public. ${ }^{133}$ Although this request was later withdrawn (and the Council released the Report in September 2000), the government's

126 University of Hong Kong Independent Investigation Panel, Report to the Council of the University of Hong Kong by The Independent Investigation Panel (Aug. 26, 2000) (copy on file with the authors).

$127 I d$. at 13 (noting that video cameras provided continuous live coverage of the hearings for broadcast media outlets). Well Worth the Wait as Plot Finally Thickens, S. ChINA MoRning Post (H.K.) (Aug 8, 2000), http://www.scmp.com/article/323250/wellworth-wait-plot-finally-thickens [https://perma.cc/NZ6A-HPDH]; Pollster's Integrity Challenged, S. CHINA MORNING Post (H.K.) (Aug 9, 2000), http://www.scmp.com/article/323304/pollsters-integrity-challenged

[https://perma.cc/2HZ5-D2MQ]; and Pollster Faced Internal Claims that Surveys were Non-Academic Activities, Panel Told, S. China Morning Post (H.K.) (Aug 10, 2000), http://www.scmp.com/article/323377/pollster-faced-internal-claims-surveys-were-nonacademic-activities-panel-told [https://perma.cc/CW58-7TR9].

128 University of Hong Kong Independent Investigation Panel, Report to the Council of the University of Hong Kong by The Independent Investigation Panel, supra note 126, at 67.

129 Id.

130 Id. at 73 .

131 Id.

132 Id. at 31.

133 Tung Aide to Lobby Against "Slurs", S. China Morning Post (H.K.), Sept. 6, 2000 . 
displeasure was clear, which made academic staff concerned that HKU's Council would try to distance itself from the Panel's findings. ${ }^{134}$

The Council Chairman, Sir T.L. Yang, was in a particularly difficult position because he was also a member of Tung Cheehwa's Executive Council (similar to a cabinet) at the time and Mr. Tung had already publicly disagreed with the Panel's findings. ${ }^{135}$ A group of HKU academics therefore drafted a petition, which was circulated by email, requesting the Council to accept the Report. ${ }^{136}$ Within three days, 439 academics, over half of the academic staff of $\mathrm{HKU}$, had signed this petition. ${ }^{137}$ Many signatories did not have tenure but probably felt somewhat reassured by the fact that the signatories included six of the nine deans, fourteen associate deans, and twenty-six heads of departments or centers within the university. ${ }^{138}$ At the time, all of the deans were elected from among their respective faculties and they all sat on HKU's Council, giving the university a reasonable balance between internal and external members. ${ }^{139}$ Although the petition did not call upon HKU's Council to take any particular action beyond adopting the Report, it demonstrated that the ViceChancellor had lost credibility with the majority of his academic staff. ${ }^{140}$

Shortly before the Council meeting resumed on September 6, 2000, the Vice-Chancellor and Pro-Vice-Chancellor Wong both

134 Id.

135 Id. (noting that Sir. T.L. Yang was simultaneously serving as Chairman of the University of Hong Kong's Council and as a member of the Tung Chee-hwa's Executive Council); see also Petersen, Lessons, supra note 21, at 172 (summarizing statements made by Tung Chee-hwa in support of his aide).

136 Petition Launched Ahead of Council Meeting on Poll Report, S. CHINA MoRNING Post (H.K.) (Sept. 4, 2000),

http://www .scmp.com/article/325483/petition-launched-ahead-council-meeting-pollreport [https://perma.cc/B5RB-J8E2].

137 Letter dated Sept. 6, 2000 to the Members of the Council, University of Hong Kong, signed by 439 academics (copy on file with the authors).

138 Id.

139 Petersen \& Currie, Higher Education, supra note 16 (documenting changes in the governance and management structure after the Robert Chung incident).

140 University of Hong Kong Academics Are Putting Careers on the Line Over the Chung Inquiry, S. China Morning Post (H.K.), Sept. 6, 2000 (describing academics' reasons for signing the petition and declining support for the Vice Chancellor). 
offered their resignations. ${ }^{141}$ They almost certainly did so in order to save the external members of HKU's Council from having to decide whether to take any formal action on the Panel's Report. After the resignations were announced, the Chairman quickly introduced a series of motions to the effect that the Council would simply "note" the Report rather than formally adopt it. ${ }^{142}$ Interestingly, the Council was careful to note only the Panel's findings regarding the Vice-Chancellor and Professor Wong, thereby distancing itself from any findings relating to Tung Cheehwa's assistant. ${ }^{143}$ This course of action was supported by the external members of the Council but objected to by the student members and the majority of the deans. ${ }^{144}$ There is little doubt that the external members were influenced by their reluctance to criticize a member of the Chief Executive's staff.

Following the Robert Chung affair, HKU established a Senate Task Force on Academic Freedom, which sought submissions from students and staff. ${ }^{145}$ The Task Force concluded that "there is evidence to suggest that a number of members of this university have felt that their academic freedoms have been infringed in a variety of ways." 146 It recommended that HKU adopt a definition of academic freedom and a list of freedoms enjoyed by members of the university, including the freedom to put forward controversial opinions, to question the governance and conduct of university affairs, to discuss university affairs in appropriate media, to select one's areas of research, and to offer expert advice in both academic and non-academic contexts. ${ }^{147}$ The Task Force also stressed that members of the university have an obligation to support academic freedom and to "avoid simply using rank or positions as a means of imposing opinions or values."148 To their credit, HKU's Council and Senate later adopted the Task Force's

141 See Petersen, Lessons, supra note 21, at 170.

142 Id. at $170-71$.

143 Id.

144 Id.

145 The University of Hong Kong, Senate Task Force on Academic Freedom, IJ 19 (2002), http://www.dental.hku.hk/biomat/TFAF/TFAF\%20Senate\%20Report.pdf [https://perma.cc/87P7-CM8W].

146 Id. I 81.

147 Id. 947.

148 Id. I 10. 
definition of academic freedom, as well as the suggested list of freedoms and responsibilities. ${ }^{149}$

Robert Chung continues to direct opinion poll research at HKU and he does not shy away from reporting on sensitive topics, including the low levels of support for the appointed Chief Executive and declining public confidence. ${ }^{150}$ Yet the saga also demonstrated how easily government officials can intimidate university councils, particularly the external members. ${ }^{151}$ In the wake of the scandal, one of the authors of this article recommended certain reforms to make the universities more autonomous, including: abolishing the Chief Executive's role as chancellor of every university; adopting a firm rule that no member of a university council could simultaneously serve as a member of the Chief Executive's Executive Council; and changing the balance of membership on university councils so that the external members would not hold a majority of the seats. ${ }^{152}$

Unfortunately, the system of university governance moved in precisely the opposite direction after the Robert Chung affair, becoming more centralized and more vulnerable to outside interference. ${ }^{153}$ This is largely due to recommendations in a 2002 report commissioned by the University Grants Committee and authored by Lord Sutherland, Vice-Chancellor of the University of Edinburgh, entitled Higher Education in Hong Kong: Report of the University Grants Committee (also known as the "Sutherland Report"). ${ }^{154}$ The Sutherland Report concluded that the system of governance used in Hong Kong's traditional universities-

\footnotetext{
149 See Academic Freedom Policy, U. Hong Kong, http://www.hku.hk/about/policies_reports/acad_freedom.html [https://perma.cc/J7VABCEY] (last visited Mar. 16, 2016).

150 See, e.g., Team Members, Public Opinion Programme, U. Hong Kong, https://www.hkupop.hku.hk/english/aboutpop/teams.html [https://perma.cc/T86M5CNV] (last visited Mar. 15, 2016) (listing the leadership team).

151 POP Polls, Public Opinion Programme, U. Hong Kong, https://www.hkupop.hku.hk/english/popexpress/ [https://perma.cc/SUC4-UV8G] (last visited Mar. 15, 2016) (listing recent polls).

152 Petersen, Lessons, supra note 21, at 175.

153 Petersen \& Currie, Higher Education, supra note 16.

154 Stewart R. Sutherland, Higher Education in Hong Kong - Report of the University Grants Committee (Mar. 2002), http://www.ugc.edu.hk/eng/ugc/publication/report/her/her.htm [https://perma.cc/7WW75224] (last visited Mar. 15, 2016) [hereinafter Sutherland Report].
} 
including elected deans and the practice of distributing governance among several bodies, such as a Council, Senate, and Faculty Boards - was old-fashioned and inappropriate for building world class universities. ${ }^{155}$ Emphasizing that universities now manage substantial public funds, the report endorsed the more centralized systems of governance that are used at leading universities in the USA, the U.K., and Australia. ${ }^{156}$ The report also expressed a strong preference for appointed deans, which is consistent with international practice but not necessarily the best approach in Hong Kong, given the lack of local democracy and the hostility towards free speech from the central government. ${ }^{157}$

Despite many academics' concerns, the recommendations of the Sutherland Report were largely endorsed by a subsequent review at HKU, known as the Fit For Purpose Report, which concluded that the "globalization of higher education and an increasingly competitive environment" require more "robust" and "streamlined" systems of governance. ${ }^{158}$ As part of these "reforms," HKU abolished the tradition of electing deans from within the faculties and it now advertises for and appoints fulltime "executive" deans. ${ }^{159}$ Although members of the faculty elect some representatives onto the relevant search committee, the ViceChancellor makes the ultimate decision on appointment and reappointment of deans and has no obligation to follow the recommendations of faculty representatives. ${ }^{160}$ Thus the deans are now a part of the Vice-Chancellor's team and almost certainly less accountable to their respective faculties. The appointed deans, in turn, now appoint HKU's heads of departments. ${ }^{161}$ In our view, had this been the case during the Robert Chung affair, it is unlikely that so many deans and heads of departments would have signed the petition that led to the Vice-Chancellor's resignation.

\footnotetext{
155 Id.

156 Id.

157 Id.

158 The University of Hong Kong, Fit For Purpose Report, at Executive Summary http://www.hku.hk/about/governance/purpose_report.html [https://perma.cc/K9S5-Q2XW] [hereinafter Fit for Purpose] (last visited Mar. 15,
159 Id.
$160 I d$.
161 Id. (2003), 2016). 
HKU also now has a smaller Council, which is even more dominated by non-university members than it was during the Robert Chung affair. ${ }^{162}$ Similar changes have been made to Hong Kong's other institutions of higher education, greatly increasing the influence of the Chief Executive. ${ }^{163}$ The Newby Report, prepared by Sir Howard Newby for the UGC in 2015, acknowledged that the Chief Executive's power to appoint the external members of universities' councils leaves the universities with "little or no control" and "places a premium on the nature of the relationship" with the Chief Executive's office. ${ }^{164}$ This puts the universities in a particularly difficult position because there are so many conflicts between the government and the academic community, a situation unlikely to change as long as Beijing refuses to allow the Hong Kong people to elect their Chief Executive. Examples of these conflicts-which have become increasingly heated in the past five years - are analyzed in the next section of the article.

\section{Conflicts between The Academic Community and the Hong Kong and Central Governments}

It is not surprising that academics at Hong Kong's universities would be deeply involved in the study of "One Country, Two Systems" and various cross-border controversies that have arisen since 1997. ${ }^{165}$ For example, Baptist University's Hong Kong Transition Project has been studying political developments in the territory since 1989, including the increasingly contentious topic of democracy. ${ }^{166}$ HKU academics associated with the CCPL also

\footnotetext{
162 The University of Hong Kong, The Council: Membership, http://www.hku.hk/about/governance/governance_structure/thecourt/council_membership.html [https://perma.cc/8KAR-SKT9] (last visited Mar. 15, 2016).

163 Petersen \& Currie, Higher Education, supra note 16.

164 Newby Report, supra note 116, at 2021.

165 Thomas P. Rohlen, Hong Kong and the Pearl River Delta: "One Country, Two Systems" in the Emerging Metropolitan Context, STANFORD INSTITUTE FOR INTERNATIONAL STUDIES 7 (July 2000).

166 See, e.g., The Hong Kong Transition Project, Hong Kong Constitutional Reform: What Do the People Want? (Dec. 2005), http://hktp.hkbu.edu.hk [https://perma.cc/GA6Q-FYEC] (last visited Mar. 14, 2016). Additional research reports available on the website of the Hong Kong Transition Project at http://hktp.hkbu.edu.hk/ [https://perma.cc/V767-MVVV] (last visited Mar. 14, 2016).
} 
have been prolific on issues relating to the implementation of the Joint Declaration, Hong Kong's Bill of Rights, and the Basic Law. ${ }^{167}$

In recent years, the most controversial subject has been whether and how Hong Kong will be permitted to develop a more democratic system of governance. There is a good deal of material for academics to study and comment upon, partly because the current system is so complicated (perhaps deliberately so), making it important for researchers to study just how the system works. For example, Centre for Comparative and Public Law published a series of research reports on the functional constituency seats in the Legislative Council, including the problem of "packing" (whereby a corporation can create additional subsidiaries and affiliated companies to increase its votes within a constituency). ${ }^{168}$ $\mathrm{HKU}$ academics also produced and commented on various proposals to nominate and elect a Chief Executive through universal suffrage. ${ }^{169}$

For academics who study law and politics, their research

167 See, e.g., The New Legal Order IN Hong Kong (Raymond Wacks, ed., H. K. Univ. Press, 1999); Roda Mushkat, One Country, Two International Legal Personalities: The Case of Hong Kong (H.K. Univ. Press 1997); Hong Kong, China AND 1997: EsSAYS IN Legal TheORY (Raymond Wacks, ed., H.K. Univ. Press 1993); INTERPRETING HONG Kong's BASIC LAW, supra note 13; and NATIONAL SECURITY AND FundAMENTAL FREEDOMS, supra note 20. Additional publications by academics associated with the CCPL are listed at http://www.law.hku.hk/ccpl/pub/index.html [https://perma.cc/JE2W-JGKE].

168 See, e.g., Young \& LAw, supra note 57, Ig 135-155. See also Centre for Comparative and Public Law, Research: Constitutional Societies, http://www.law.hku.hk/ccpl/research/ConstitutionalSocieties.html [https://perma.cc/CR8L-VDTC] (last visited Mar. 15, 2016) (showing additional reports on the functional constituency system).

169 See, e.g., Stuart Lau, Basic Law Expert Albert Chen Tries to Steer Middle Road on Reform for Hong Kong Chief Executive Election, S. ChInA MoRning Post (Jan. 26, 2015, 5:49 AM), http://www.scmp.com/news/hong-kong/article/1691393/basic-lawexpert-albert-chen-tries-steer-middle-road-reform-hong-kong [https://perma.cc/739FQ4RV]; see also Stuart Lau, 'Dual Track' Nomination System for 2017 Chief Executive Election Proposed by Law Scholar, S. CHINA MoRnING PosT (Apr. 1, 2014, 11:57 AM), http://www scmp.com/news/hong-kong/article/1462336/dual-track-system-2017-chiefexecutive-election-proposed-law-scholar [https://perma.cc/576K-E5MW] (discussing Professor Simon N. M. Young's proposal); see generally, Academic Roundtable at the Centre for Comparative and Public Law at The Univ. of Hong Kong, Universal Suffrage and Nomination Procedures: Imperatives from Article 25 ICCPR (Mar. 20, 2014), http://www.law.hku.hk/ccpl/events/Article25ICCPR.html [https://perma.cc/N6KJ-2GJ2] (containing experts' viewpoints on equal and universal suffrage under Article 25). 
interests and their political activities often naturally overlap. For example, as a Professor of Political Science at City University, Joseph Cheng Yu-shek has published extensively on political movements in Hong Kong. ${ }^{170}$ He also served as the convener of the Alliance for True Democracy and has endeavored to moderate between different factions within Hong Kong's pro-democracy movement. $^{171}$ At the other end of the political spectrum, Ms. Priscilla Leung holds the rank of Associate Professor of Law at City University, ${ }^{172}$ while also serving as a legislator and political commentator who regularly champions pro-Beijing views. ${ }^{173}$ Indeed, if one scans the biographies of members of the Legislative Council, the District Councils, and the political parties, one will find many academics listed there. ${ }^{174}$ As their political positions are generally not "full-time," this means that many academics are wearing two hats-one as a politician and one as a lecturer or professor at a university. ${ }^{175}$ There are no rules against this in Hong Kong - and in fact, many members of the Legislative Council maintain other careers. However, that so many university employees are in the thick of the debate on democratic reform in Hong Kong - not simply as researchers and commentators but as active political campaigners-naturally increases the tension between government officials and the academic community.

170 Tanna Chong, Professor Joseph Cheng Yu-Shek, a Peace Broker at Breaking Point, S. China Morning Post (Jan. 13, 2014), http://www.scmp.com/news/hongkong/article/1404121/professor-joseph-cheng-yu-shek-peace-broker-breaking-point [https://perma.cc/EF4R-VLWG].

171 See id.

172 See Staff Profile for Priscilla Leung, City University School of LAw, http://www6.cityu.edu.hk/slw/people/people_priscilla.html [https://perma.cc/R9AK2UJA] (last visited Sept. 16, 2016).

173 See Business And Professionals Alliance of Hong Kong, http://bpahk.org/eng/ [https://perma.cc/Z7VH-RR26] (showing the homepage of Leung's political party).

174 See Members' Biographies, Legislative Council of the Hong Kong SAR, http://www.legco.gov.hk/general/english/members/yr16-20/biographies.htm (last visited Jan. 25, 2017) (showing for example, that Legislator Helena Wong (of the Democratic Party) is also a lecturer at Hong Kong Polytechnic University, Joseph Lee is a Professor at the Open University of Hong Kong, and Priscilla Leung is an Associate Professor at the City University of Hong Kong) [hereinafter Biographies]; see also Dr. Hon Fernando Cheung Chiu Hung, http://en.cheungchiuhung.org.hk/about-us/fernando-cheung-chiuhung/ [https://perma.cc/7EQ8-C3LG] (last visited Sept. 16, 2016) (providing the biography of Legislative Councilor Fernando Cheung).

175 Id. 
These conflicts have become especially acute in recent years. Beijing has delayed democracy reforms, making the local appointed government all the more unpopular and, therefore, more sensitive to critical research projects and advocacy. Although the Basic Law expressly provides for democratic reform, it pinpoints the second decade after reunification as the first time that significant changes can be made. Article 45 states that there shall be "gradual and orderly progress" in the method of selecting the Chief Executive, and that the "ultimate aim" is selection "by universal suffrage upon nomination by a broadly representative nominating committee in accordance with democratic procedures." orderly progress" toward the ultimate aim of electing "all members of the Legislative Council by universal suffrage." ${ }^{\prime 77}$ This would appear to expressly allow for the eventual abolition of the functional constituency seats. Yet the Annexes to the Basic Law set forth procedures that must be followed in order to move in this direction and establish substantial hurdles. ${ }^{178}$

For example, Annex I to the Basic Law provides that: "If there is a need to amend the method for selecting the Chief Executive for the terms subsequent to the year 2007," such amendments must be endorsed by a two-thirds majority of the Legislative Council, approved by the Chief Executive, and reported to the NPCSC for approval. ${ }^{179}$ Annex II requires a similar procedure for changes to the method of selecting the Legislative Council, except that it states that the changes must be reported to the NPCSC "for the record" (rather than "for approval"). ${ }^{180}$ In practice, this language does not make a great deal of difference, because the appointed Chief Executive would almost certainly withhold his consent to any changes that the central government was not prepared to approve.

Beijing has consistently exploited the procedural requirements in the Annexes in order to delay the pace of reform, ${ }^{181}$ using its

176 Basic Law, supra note 1, art. 45 (showing that the Central People's Government will appoint the Chief Executive after s/he is selected or elected locally).

177 Id. art. 68.

178 Id. Annex I-II.

179 Id. Annex I.

180 Id. Annex II.

181 See Alvin Y.H. Cheung, Road to Nowhere: Hong Kong's Democratization and 
power to interpret the Basic Law (pursuant to Article 158) to create new barriers. ${ }^{182}$ For example, in 2004, in response to the July 2003 march against national security legislation and strong performance of pro-democracy parties in that year's District Council elections, the NPCSC issued an interpretation of Annexes I and II that arrogated to itself the right to determine whether electoral reform was "necessary," following a report from the Chief Executive. ${ }^{183}$ Unsurprisingly, then-Chief Executive Tung advised, ${ }^{184}$ and the NPCSC declared, that such reforms were not necessary for the Chief Executive elections in 2007 and legislative elections in 2008. ${ }^{185}$ In 2007, the NPCSC, again responding to political pressure on the Hong Kong government, declared that

China's Obligations Under Public International Law, 40 BRooK. J. INT'L L. 465, 481504 (2015) (describing the history of Beijing's efforts to thwart democratization in Hong Kong).

182 See supra note 64 (containing English translations of instruments that the Hong Kong government publishes, including the NPCSC's interpretations of the Basic Law and its "decisions" blocking democratic reform, describing them as "instruments" and treating them as equivalent to the text of the Basic Law).

183 See Quanguo Renmin Daibiao Dahui Changwu Weiyuanhui Guanyu Zhonghua Renmin Gongheguo Xianggang Tebie Xingzhengqu Jibenfa Fujian Yi Di Qi Tiao He Fujian Er Di San Tiao de Jieshi, (全國人民代表大會常務委員會關於《中華人民共和 國香港特別行政區基本法》附件一第七條和附件二第三條的解釋), [Interpretation by the Standing Committee of the National People's Congress of Article 7 of Annex I and Article III of Annex II to the Basic Law of the Hong Kong Special Administrative Region of the People's Republic of China] Standing Comm. Nat'l People's Cong. (Apr. 6, 2004), http://www.npc.gov.cn/wxzl/wxzl/2004-07/23/content_332218.htm [https://perma.cc/R9X2-DD98] [hereinafter 2004 Interpretation].

184 See H.K. ChIEF EXec., Report on Whether There is a NEED to AMEND the METHODS FOR SELECTING THE CHIEF EXECUTIVE OF the HoNG Kong SPECIAL ADMINISTRATIVE REGION IN 2007 AND FOR FORMING THE LEGISLATIVE COUNCIL OF THE HONG KONG SPECIAL ADMINISTRATIVE REGION IN 2008, 4 (2004), http://www.basiclaw.gov.hk/en/materials/doc/2004_04_15_e.pdf [https://perma.cc/Y6DV-9VSC].

185 See Quanguo Renmin Daibiao Dahui Changwu Weiyuanhui Guanyu Xianggang Tebie Xingzhengqu 2012 Nian Xingzheng Zhangguan He Lifa Hui Chansheng Banfa Ji Youguan Puxuan Wenti de Jueding (全國人民代表大會常務委員會關於香港特別行政 區2012年行政長官和立法會 $\square$ 生辦法及有關普選問題的決定), [Decision of the Standing Committee of the National People's Congress on Issues Relating to the Methods for Selecting the Chief Executive of the Hong Kong Special Administrative Region and for Forming the Legislative Council of the Hong Kong Special Administrative Region in the Year 2012 and on Issues Relating to Universal Suffrage] Standing Comm. Nat'l People's Cong. (Dec. 29, 2007), http://www.npc.gov.cn/npc/xinwen/syxw/2007-12/29/content_1387576.htm [https://perma.cc/62WH-J8BK] [hereinafter 2007 Decision]. 
there would be no election by universal suffrage in $2012 .{ }^{186}$

Faced with a line of NPCSC decisions delaying democratization, Hong Kong's democrats became bitterly divided about how to react. In November 2009, the Hong Kong government released modest proposals on Chief Executive and legislative electoral reforms for 2012. ${ }^{187}$ In response, five legislators-one from each of the territory's geographical constituencies-resigned in order to trigger a "de facto referendum" on reform. ${ }^{188}$ However, the Democratic Party of Hong Kong - then the largest pro-democracy party-declined to participate, instead entering into secret negotiations with Beijing's liaison office in Hong Kong (the "Liaison Office"). ${ }^{189}$ Although the reform proposals were narrowly passed in 2010, they provoked a severe backlash against the Democratic Party, splitting the prodemocracy camp-and intensifying public demands for democratization. ${ }^{190}$

In the midst of this tension, Donald Tsang (the second Chief Executive, who served from 2005-2012) threw more fuel on the fire by emphasizing, in his 2010-11 policy address, the importance of national unity and of strengthening "national education" in local schools. ${ }^{191}$ Although the topic of national education had been raised in previous policy addresses, this time the government had a concrete plan in mind. In 2011, the local Education Bureau issued a public consultation document stressing the need to develop "affection for the country" and "national identity." ${ }^{192}$ In 2012, it

186 See id.

187 H.K. Const. and Mainland Aff. Bureau, Consultation Document on the Methods for Selecting the Chief Executive AND for Forming the Legislative $\begin{array}{lllll}\text { COUNCIL IN } & 2012 & \text { (Nov. } & 18, & \text { 2009), }\end{array}$ http://www.gov.hk/en/residents/government/publication/consultation/docs/2010/CE_and _LC_in_2012.pdf [https://perma.cc/V6YM-KWKC].

188 Protest Vote, ECONOMIST (May 20, 2010), http://www .economist.com/node/16167654 [https://perma.cc/R8NH-HEFY].

189 Albert H.Y. Chen, An Unexpected Breakthrough in Hong Kong's Constitutional Reform, 40 H.K.L.J. 259, 259-60 (2010).

190 See id. at 265.

191 See Donald Tsang, The 2010-11 Policy Address: Sharing Prosperity for a Caring Hong Kong, 47 (2010), http://www.policyaddress.gov.hk/10-11/eng/pdf/policy.pdf [https://perma.cc/ZG8C-HA3H].

192 See Ad Hoc Committee on Moral and National Education Curriculum Development Council, Consultation on Moral and National Education Curriculum (Summary), $11 \quad$ (2011), http://www.edb.gov.hk/attachment/en/curriculum- 
published a curriculum guide. ${ }^{193}$ In the same year, a governmentfunded body, the National Education Services Centre, distributed a teaching handbook that described the Chinese Communist Party as "progressive, selfless, and united," implying that China's one party state was superior to multiparty democracies. ${ }^{194}$

The suggested curriculum was strongly criticized by the public, both as a form of brainwashing, and as a violation of Hong Kong's autonomy in the field of education. ${ }^{195}$ Large protests were organized by multiple coalitions, including the National Education Parents' Concern Group, the Civil Alliance Against the National Education, and Scholarism - a relatively new student organization. The protests attracted thousands of people and gained international attention, launching the political career of Scholarism's young leader, Joshua Wong (who would go on to be a key organizer of the pro-democracy protests in 2014)..$^{196}$

The sheer scale of the anti-patriotic education protests created a sense of crisis early in the first term of the third Chief Executive, C.Y. Leung, who had only assumed office in July 2012. Looking for a way to defuse the situation, Leung asked one of the few liberal members of his Executive Council, Anna $\mathrm{Wu}$, to chair a "Committee on the Initiation of Moral and National Education.". 197 After three meetings, the Committee recommended that the government "shelve" its curriculum guidelines, and that local

development/moral-national-edu/Consultation_on_MNE_Curriculum_(Summary)_2.pdf [https://perma.cc/Z5JK-HEGE].

193 See Ad Hoc Committee on Moral and National Education Curriculum Development Council, Moral and National Education Curriculum Guide: Primary 1 to Secondary 6, 7-8, 15 (2012), http://www.edb.gov.hk/attachment/en/curriculumdevelopment/moral-nationaledu/MNE\%20Guide\%20(ENG)\%20Final_remark_09102012.pdf [https://perma.cc/U62U-YT2L].

194 See Joyce Lau, Thousands Protest In Hong Kong Against China's Move to Impose Curriculum, N.Y. TIMES, July 30, 2012, at A4.

195 Id.

196 See Malcolm Moore, Portrait of Hong Kong's 18-year old Protest Leader, TELEGRAPH (London), (Dec. 11, 2014), http:// www.telegraph.co.uk/news/worldnews/asia/hongkong/11139904/Portrait-of-HongKongs-17-year-old-protest-leader.html [https://perma.cc/LL3U-HPWU].

197 See Dennis Chong, Anna Wu: Liberal Icon Who Can Handle Political Hot Potato, S. China Morning Post (Oct. 15, 2012, 12:00 AM), http://www scmp.com/news/hong-kong/article/1061127/liberal-icon-who-can-handlepolitical-hot-potato [https://perma.cc/2PHQ-YPFS]. 
schools should exercise complete autonomy over whether, when, and how to teach the subjects of moral and national education. ${ }^{198}$ Although the Chief Executive quickly agreed, there is a lingering fear in Hong Kong that this battle is not over. Moreover, that the local Hong Kong government could not implement the new curriculum-like its failure to implement Article 23 legislation in 2003-has made Beijing even more suspicious of grassroots movements in Hong Kong and more opposed to meaningful democratic reforms.

Against this background of growing political acrimony, securing consensus on a more democratic method of selecting the Chief Executive in 2017 would have been difficult at best. Yet neither the pro-democracy leaders nor Beijing made significant strides to lower the political temperature. In a speech on March 24, 2013, NPC Law Committee Chairman Qiao Xiaoyang declared that any candidate for Chief Executive must "love the country and love Hong Kong," adding that no person who "confronted" the Central Government could become Chief Executive. ${ }^{199}$ Similar rhetoric about "loving the country and loving Hong Kong" had featured in previous debates over democratization. However, Qiao's speech contained an additional threat. Beijing's patience, he declared, had worn thin; no consultations on further reforms could begin unless Hong Kong's democrats accepted that no "confrontational" candidate could become Chief Executive. ${ }^{200}$ Despite widespread democratic uproar, the Hong Kong government took Qiao's speech as its template for electoral consultations; the ensuing consultation document was widely panned as being a purely cosmetic exercise. ${ }^{201}$

198 See generally Education Bureau H.K., Moral and National Education, http://www.edb.gov.hk/en/curriculum-development/moral-national-edu/

[https://perma.cc/VG6Z-NQFY] (last visited Sept. 16, 2016) (containing transcripts of speeches delivered when the government accepted the Committee's recommendation to "shelve" the national education initiative).

199 See Xiaoyang Qiao, 喬曉陽在香港立法會部分議員座談會上的講話 [Qiao Xiaoyang's Remarks at a Seminar With Some Members of the H.K. Legislative Council] (Mar. 24, 2013), http://www.locpg.gov.cn/shouyexinwen/201303/t20130327_7135.asp [https://perma.cc/4NPE-KJCS].

200 Id.

201 See, e.g., Au Nok-hin, 京官是聖旨的政改諮詢 [A Political Reform Consultation Where Beijing's Officials Dictate Holy Orders], MingPaO (H.K.), Dec. 6,

2013. 
In January 2013, a soft-spoken Associate Professor of Law at HKU named Benny Tai began writing about a new initiative, which he dubbed Occupy Central with Love and Peace ("Occupy Central"). ${ }^{202}$ Tai proposed that Hong Kong residents should not wait indefinitely, but rather should set a deadline and take meaningful action if Beijing continued to refuse to allow the territory to elect its Chief Executive through universal suffrage. ${ }^{203}$ On March 27, 2013, Tai formally launched the movement, together with Chan Kin-man, a sociology professor from Chinese University, and Reverend Chu Yiu-ming. ${ }^{204}$ The movement appealed to many Hong Kong residents who were growing frustrated with China's continued opposition to democratic reforms. If the final electoral reform proposals did not conform with international standards of universal suffrage, Occupy Central declared, it would engage in concerted civil disobedience in the form of blockading the city's business district. ${ }^{205}$ Although firmly committed to nonviolence, the Occupy Central organizers also made it clear that they were prepared to violate the law and go to jail if necessary. ${ }^{206}$

Given that two of the three leaders of Occupy Central were academics, it was perhaps inevitable that Beijing would associate the movement with Hong Kong's universities. ${ }^{207}$ The Occupy Central Secretariat also commissioned HKU's Public Opinion Programme, led by Dr. Robert Chung, to conduct an Occupy Central "Deliberation Series," which applied the deliberative democracy model to "invite the general public and campaign supporters to join the discussion" and ensure that any polling of public opinion on the various democracy proposals would comply with international standards. ${ }^{208}$ Although the Public Opinion

\footnotetext{
202 See generally OcCuPy Central with LOVE AND PEACE (2016), http://oclp.hk/index.php?route=occupy/eng_detail\&eng_id=28 [https://perma.cc/Z6ULQYNP] (explaining the philosophy behind non-violent protest). 
Program maintained its political neutrality, and therefore never endorsed Occupy Central or any particular model of governance, its very participation in activities initiated by Occupy Central would have displeased pro-Beijing forces. HKU's Centre for Comparative and Public Law also held many public events on constitutional reforms during 2013 and 2014, ${ }^{209}$ including an international "roundtable" on the relationship between Article 25 of the ICCPR, which guarantees the right to political participation, and Article 45 of the Basic Law, which provides for a nominating committee to nominate candidates for Chief Executive. ${ }^{210}$ At the conclusion of the roundtable, the participants issued a press release expressing the view that a proposal could comply with both Article 25 of the ICCPR and Article 45 of the Basic Law if the nominating committee were truly representative of the public. ${ }^{211}$ Implicitly, these academics were suggesting that compromise was possible. ${ }^{212}$ Many other academics proposed models that would maintain a nominating committee, but would make it more representative. ${ }^{213}$

However, neither Beijing nor the organizers of Occupy Central were in the mood for compromise and both sides continued to ratchet up tensions during 2014. Increasingly bellicose rhetoric from Beijing culminated in the PRC State Council's "White Paper" of June 10, 2014, which declared that Beijing "directly

209 See Events: Conferences \& Seminars, Centre Comparative And Pub. L., Fac. L. U. H.K., http://www.law.hku.hk/ccpl/events/ConferencesSeminars.html\#2014 [https://perma.cc/2A7N-RL77] (follow “2014” hyperlink).

210 See Academic Roundtable: "Universal Suffrage and Nomination Procedures: Imperatives from Article 25 ICCPR”, CENTRE COMPARATIVE AND PUB. L., FAC. L. U. H.K., (Mar. 20, 2014), http://www.law.hku.hk/ccpl/events/Article25ICCPR.html [https://perma.cc/XL6M-V9JB].

211 See generally Guiding Principles, Centre Comparative and Pub. L., Fac. L. U.

H.K. (Mar. 21, 2014), http://www.law.hku.hk/ccpl/events/CCPL\%20Article\%2025\%20Roundtable\%20Press\% 20Release\%20on\%20Guiding\%20Principles\%2021\%20March\%202014.pdf [https://perma.cc/Q5PY-TGSM] (providing the text of the press release).

212 See generally Participant Commentary, Centre Comparative And Pub. L., FaC. L. U. H.K. (Mar. 20, 2014), http://www.law.hku.hk/ccpl/events/Comments_ICCPR_27_March.pdf [https://perma.cc/XQH5-F87S] (providing the comments of the participants).

213 See generally Eric Cheung, Achieving True Democracy Under the Basic Law, Centre Comparative and Pub. L., Fac. L. U. H.K. (2014), https://www.law.hku.hk/ccpl/events/Eric\%20Cheung\%20(eng)\%20Statement.pdf [https://perma.cc/2YYC-N3S9] (explaining the proposal signed by eighteen academics from seven of Hong Kong's institutions of higher education). 
exercises jurisdiction over the HKSAR" and demanded that "all those who administrate Hong Kong" must be "patriotic." 214 For its part, Occupy Central held a referendum between June 20 and June 29 , and nearly 800,000 voters participated, despite "one of the largest and most sophisticated denial-of-service attacks in the Internet's history." 215 An overwhelming majority of participating voters agreed that the legislature should reject any proposal inconsistent with international standards. ${ }^{216}$ Nonetheless, the Hong Kong government's consultation report stated that "mainstream opinion" backed the political vetting of Chief Executive candidates. $^{217}$

Although some commentators remained optimistic about the possibility of compromise, the NPCSC dashed all such hopes with its Decision of August 31, 2014, which entrenched the requirement that any Chief Executive "love the country and love Hong Kong." 218 In practical terms, it required: (a) between two and three

214 See The Practice of the "One Country, Two Systems" Policy in the Hong Kong Special Administrative Region, OfFICE COMM'R Ministry Foreign AFFAIRS CHINA H.K. SPECIAL ADMIN. REGION (June 10, 2014), http://www.fmcoprc.gov.hk/eng/xwdt/gsxw/t1164057.htm [https://perma.cc/Y7EACDZ2] [hereinafter White Paper].

215 See Paul Mozur \& Chester Yung, Hong Kong Democracy Poll Hit by Cyberattack, WaLl ST. J. (June 20, 2014), http://online.wsj.com/articles/hong-kongdemocracy-poll-is-hit-by-cyberattack-1403258663; see also Hong Kong Democracy "Referendum" Draws Nearly 800,000, Brit. BroAdCASTING CORP. (June 30, 2014), http://www.bbc.com/news/world-asia-china-28076566 [https://perma.cc/7FMB-UEH6].

216 See Hong Kong's Democracy Debate, BRIT. BroAdCASTING CORP. (June 15, 2014), http://www.bbc.com/news/world-asia-china-27921954 [https://perma.cc/MH9GWX34].

217 See, e.g., Suzanne Pepper, Telling Beijing What Beijing Wants to Hear, CHINA Elections \& GOVERNANCE Blogs (July 17, 2014), http://chinaelectionsblog.net/hkfocus/?p=915 [https://perma.cc/CNN8-2P2T]; see also No Panderers, Please: This Issue's Black and White, ECONOMist (July 19, 2014), http://www .economist.com/news/leaders/21607855-time-britain-rediscover-its-moralcompass-and-confront-china-over-hong-kong-no-panderers [https://perma.cc/RMV5H5T9]. The "mainstream opinion" in question appears to have consisted in large part of pro forma submissions sent as a result of mobilization by pro-Beijing parties. See 建制 表格式意見書 製造萬計民意 [Establishment Parties' Pro-Forma Submissions Create Tens of Thousands in Public Opinion], MingPaO (July 16, 2014), http://news.mingpao.com/pns/\%E5\%BB\%BA\%E5\%88\%B6\%E8\%A1\%A8\%E6\%A0\%B C\%Е5\%BC\%8F\%Е6\%84\%8F\%Е8\%A6\%8B\%E6\%9B\%B8\%20\%20\%Е8\%A3\%BD\%Е 9\%80\%A0\%E8\%90\%AC\%E8\%A8\%88\%E6\%B0\%91\%E6\%84\%8F/web_tc/article/201 40716/s00001/1405447440737 [https://perma.cc/U89P-ZS4H].

218 See generally Quanguo Renmin Daibiao Dahui Changwu Weiyuanhui Guanyu 
candidates for Chief Executive, (b) candidates to be chosen by a 1,200-strong Nominating Committee structured in the same way as the extant Election Committee, (c) each candidate to receive support from at least half of the nominators - a dramatic increase from the one-eighth threshold required for nomination in 2012, and (d) all candidates to "love the country and love Hong Kong." 219 The upshot of the 2014 Decision was that only politicians deemed politically palatable to Beijing could run-an outcome Lawrence Lessig described as "Tweedism updated.",220

In the wake of the 2014 Decision, Occupy Central organizer Benny Tai declared, "[t]he road of dialogue has come to the end."221 The Hong Kong Federation of Students ("HKFS"), an organization composed of university student unions, organized a weeklong class boycott starting on September 22, 2014; on the night of September 26, protesting students scaled a fence to enter the forecourt of Hong Kong government headquarters, known as Civic Square. ${ }^{222}$ Police moved in with batons and pepper spray; Joshua Wong, along with HKFS leaders Alex Chow and Lester Shum, were taken into custody. ${ }^{223}$ The next day, police fired

Xianggang Tebie Xingzhengqu Xingzheng Zhangguan Puxuan Wenti He 2016 Nian Lifa Hui Chansheng Banfa De Jueding, (全國人民代表大會常務委員會關於香港特別行政 區行政長官普選問題和 2016 年立法會 $\square$ 生辦法的決定) [Decision of the Standing Committee of the National People's Congress on Issues Relating to the Selection of Chief Executive of the Hong Kong Special Administrative Region by Universal and Suffrage on the Method for Forming the Legislative Council of the Hong Kong Special Administrative Region In the Year 2016] Standing Comm. Nat'l People's Cong. (Aug. 31, 2014), http://www.basiclaw.gov.hk/en/basiclawtext/index.html [https://perma.cc/K36N-68N5] (containing an English translation of this and other Decisions by the NPCSC at Instrument 24).

219 Id.

220 See Lawrence Lessig, We Should Be Protesting, Too, Huffington Post (Oct. 1, 2014, 8:47 PM), http://www.huffingtonpost.com/lawrence-lessig/we-should-beprotesting-too_b_5917486.html [https://perma.cc/L2YY-JH43].

221 See Political City: Denied Free Elections, Hong Kong's Democrats Plan, Reluctantly, for Protest, ECONOMIST (Sept. 6, 2014), http://www.economist.com/news/china/21615636-denied-free-elections-hong-kongsdemocrats-plan-reluctantly-protest-political-city [https://perma.cc/Z4AQ-9RDN].

222 See Elizabeth Barber \& Charlie Campbell, Pro-Democracy Students Storm Government Square in Hong Kong, TIME (Sept. 27, 2014, 2:40 AM), http://time.com/3434099/protest-arrested-hong-kong-democracy-students-occupycentral/ [https://perma.cc/WWA8-D4MS].

223 See Mehul Strivastava et al., How Tear Gas Attack Ignited Hong Kong Democracy Protests, BLOOMBERG (Oct. 9, 2014), http://www.bloomberg.com/news/articles/2014-10-09/how-hong-kong-got-caught-off- 
eighty-seven canisters of teargas at unarmed protesters gathered near Civic Square in support of the students. ${ }^{224}$ In the early hours of September 28, Benny Tai declared that Occupy Central had begun. ${ }^{225}$ While the occupation was remarkably peaceful-and ended with minimum violence in December-it attracted significant international attention and was an embarrassment to the Central government. ${ }^{226}$

Beijing did not openly intervene but rather left the matter in the hands of the Hong Kong government and the local police. ${ }^{227}$ However, as demonstrated in the next section, it would later launch a concerted campaign against its perceived political enemies in Hong Kong, taking full advantage of its increased influence over university councils and the more centralized structures of governance.

\section{Beijing's Retribution: Increased Interference in Hong Kong Universities}

An early-and particularly overt-example of Beijing's political purge in Hong Kong was the refusal by HKU's Council to appoint Professor Johannes Chan to a senior administrative position. $^{228}$ In the fall of 2014, HKU appointed a Search

guard-by-student-protests [https://perma.cc/WMK4-3YTH].

224 Id.

225 Id.

226 See Stephen Young, World Must Hold Beijing Accountable for its Actions in Hong Kong, S. ChinA Morning Post (Dec. 8, 2014, 4:59 PM), http://www.scmp.com/comment/insight-opinion/article/1657363/world-must-hold-

beijing-accountable-its-actions-hong-kong [https://perma.cc/AC2K-CMK3] (op-ed by former U.S. Consul-General to Hong Kong); see also Occupy Endgame Calls for Voluntary Retreat, S. CHINA MORNING Post (Dec. 4, 2014, 3:31 AM), http://www.scmp.com/comment/insight-opinion/article/1655007/occupy-spins-outcontrol-endgame-requires-voluntary-retreat [https://perma.cc/ZD8S-7LM3]; see generally Frank Ching, The Government Must Take Responsibility for Ending Occupy Protests, S. China Morning Post (Dec. 3, 2014, 6:16 PM), http://www.scmp.com/comment/insight-opinion/article/1653815/government-must-takeresponsibility-ending-occupy-protests [https://perma.cc/9EQP-L8YQ] (commenting on the abnormal state of affairs).

227 See Keith Bradsher \& Chris Buckley, Beijing is Directing Hong Kong Strategy, Government Insiders Say, N.Y. TIMES (Oct. 17, 2014), http://www .nytimes.com/2014/10/18/world/asia/china-is-directing-response-to-hongkong-protests.html?_r=0 [https://perma.cc/P2RX-YSG3].

228 For another account of interference with academic freedom in Hong Kong in recent years, see Johannes M.M. Chan and Douglas Kerr, Academic Freedom: Political 
Committee (which included the Vice Chancellor) to lead an international search to fill five Pro-Vice-Chancellor positions. ${ }^{229}$ In November of that year, rumors surfaced that Johannes Chan, the former Dean of HKU's Law Faculty, was a candidate for the position of Pro-Vice-Chancellor for academic staffing and resources. ${ }^{230}$ There are many reasons why the local and central governments would not have been happy with this choice. Johannes Chan had been a founding member of the Article 23 Concern Group, which had helped to raise public awareness concerning the national security legislation, as discussed in Part III above. That organization later evolved into the "Article 45 Concern Group," which was devoted to studying democracy proposals. $^{231}$ Over the years, Johannes Chan had also joined other moderate pro-democracy organizations, including the Civic Commission on Democratic Reform and "Hong Kong 2020," an organization dedicated to political reforms in the territory. ${ }^{232}$ Moreover, while Professor Chan himself was not involved in Occupy Central, some pro-Beijing forces blamed him for it, because he was Dean of the Law Faculty when his colleague, Benny Tai, began to plan Occupy Central. ${ }^{233}$ In a sign of Beijing's

Interference, and Public Accountability: The Hong Kong Experience, 7 J. OF ACAD. FREEDOM (2016).

229 Alan Yu \& Joyce Ng, Why the Scuffle? Hong Kong University's Appointment Controversy Explained in 6 Points, S. CHINA MORnING POST (July 29, 2015), http://www scmp.com/news/hong-kong/education-community/article/1844800/whyscuffle-hong-kong-universitys-appointment [https://perma.cc/8RFK-3VE7].

230 See, e.g., Kris Cheng, Explainer: The HKU Council Pro-Vice-Chancellor Debacle, H.K. FREE PRESS (Sept. 30, 2015, 3:29 PM), https://www .hongkongfp.com/2015/09/30/explainer-hku-council-rejects-johannes-chanappointment-to-pro-vice-chancellor/ [https://perma.cc/38N7-X8XT] [hereinafter Cheng, Explainer].

231 See, e.g., Jimmy Cheung, New Party to Fight for Democracy, S. China Morning Post (Mar. 21, 2006, 12:00 AM), http://www.scmp.com/article/541329/new-party-fightdemocracy [https://perma.cc/2VSV-27XZ] (discussing that several prominent members of the Article 45 Concern Group would go on to form the pro-democracy Civic Party in 2000).

232 See Academic Staff, Professor Johannes M.M. Chan SC (Hon), Academic Staff, FAC. L. U. HONG KONG, https://www.law.hku.hk/faculty/staff/chan_johannes.php [https://perma.cc/4DP9-3BTF] (last visited Sept. 16, 2016).

233 See Joyce Ng \& Tony Cheung, Former University of Hong Kong Law Dean Cleared of Mishandling Occupy-Related Donation, S. ChInA MoRning Post (H.K.) (Mar. 27, 2015, 12:14 AM), http://www.scmp.com/news/hongkong/article/1748042/former-university-hong-kong-law-dean-johannes-chan-cleared 
discontent, the Wen Wei Po, a Hong Kong-based Communist Party mouthpiece, began publishing articles that were highly critical of Chan. ${ }^{234}$ This did not deter the Search Committee, which unanimously recommended Chan's appointment in December $2014 .^{235}$

However, the Search Committee's recommendation needed to be confirmed by HKU's Council and the smear campaign against Professor Chan continued. In January 2015 the pro-Beijing media obtained a leaked copy of a University Grants Committee report, and claimed that it provided evidence that HKU Law Faculty's research performance had declined during Chan's deanship, allegedly due to his involvement in politics. ${ }^{236}$ The next month, Sophia Kao, a top advisor to Chief Executive C.Y. Leung, admitted that she had discussed Chan's fitness for the Pro-ViceChancellorship with unnamed persons, raising suspicions that the Chief Executive opposed Chan's appointment. ${ }^{237}$

In June 2015, perhaps due to governmental pressure, the HKU Council had not voted on whether to appoint Chan as Pro-ViceChancellor. Instead, it voted to delay the decision - again - until a new provost was appointed. ${ }^{238}$ This purported explanation drew considerable skepticism, ${ }^{239}$ not least because the absence of a

[https://perma.cc/7TSS-ARC] (showing that although Wen Wei Po published allegations that Johannes Chan had directed research funding to Occupy Central, he was later cleared of that allegation).

234 See 程翔 [Ching Cheong], 尊重事實: 港大校友不笨! [Respect the Facts: HKU Alumni Are Not Fools!], H.K. ECON. J. (Sept. 10, 2015), http://forum.hkej.com/node/125612 [https://perma.cc/HN6F-LYLY].

235 Cheng, Explainer, supra note 230.

236 See Stuart Lau, "Cultural Revolution Style” Attacks on HKU Threaten Academic Freedom: Former Law Dean, S. ChinA Morning Post (Feb. 3, 2015, 1:00 PM), http://www.scmp.com/news/hong-kong/article/1700262/cultural-revolution-style-attackshku-threaten-academic-freedom?page=all [https://perma.cc/D8P8-EDMQ].

237 See Ada Lee, Joyce Ng, Tony Cheung \& Gary Cheung, Ex-HKU Law Dean Johannes Chan Calls for Review of Government's Universities Role, S. CHINA MORNING PosT (Feb. 13, 2015, 11:26 AM), http://www.scmp.com/news/hongkong/article/1711745/former-hku-law-dean-calls-review-governments-universitiesrole?page=all [https://perma.cc/E44C-SHDV].

238 See Joyce $\mathrm{Ng}$, Jeffie Lam \& Shirley Zhao, Delayed Hong Kong University Appointment Irks Candidate Recruiter, S. ChINA Morning Post (July 3, 2015), http://www .scmp.com/news/hong-kong/education-community/article/1831780/delayedhong-kong-university-appointment-irks?page=all [https://perma.cc/P3YS-L95Z].

239 See, e.g., Alan Leong, HKU Under Threat as CY Leung Wages War on Hong Kong's Core Values and Institutions, H.K. FreE PRESS (Aug. 2, 2015), 
provost had not prevented the Council from filling the other four Pro-Vice-Chancellorships. ${ }^{240}$ The Council's continued prevarication prompted students to storm the next Council meeting in July of $2015 .^{241}$ The student body was not alone in its outrage. The HKU Convocation (a body composed of staff and alumni) convened an emergency meeting on September 1, 2015; at that meeting it overwhelmingly voted in favor of Chan's immediate appointment. $^{242}$ Despite widespread opprobrium, the Council voted against Chan's appointment on September 29, 2015, giving no official statement of reasons other than the "best interests" of HKU. ${ }^{243}$ To our knowledge, this is the first time in HKU's history that the HKU Council has rejected a recommendation of a Search Committee. ${ }^{244}$

Two particular features of the media campaign against Chan bear mentioning. First, the attacks were based at least in part on a UGC report leaked to the pro-Beijing press, suggesting an attempt by a UGC insider to target Chan. ${ }^{245}$ Second, the extent of the smear campaign against Chan was unprecedented. Between November 2014 and September 5, 2015, the Wen Wei Po, along

https://www.hongkongfp.com/2015/08/02/hku-under-threat-as-cy-leung-wages-war-onhong-kongs-core-values-and-institutions/ [https://perma.cc/2GK8-PXF4].

240 See HKU Appoints Two New Pro-Vice-Chancellors and the Dean of Arts, U. H.K. (Nov. 26, 2014), http://www.hku.hk/press/press-releases/detail/12020.html [https://perma.cc/V9SN-UBBS]; HKU Appoints Two New Pro-Vice-Chancellors, U. H.K. (Mar. 10, 2015), http://www.hku.hk/press/press-releases/detail/12433.html [https://perma.cc/LAD5-C3XC].

241 See Arthur Lo, Students Occupy HKU Council Meeting Over Pro-VC Appointment; Two Members Hospitalised, H.K. FreE Press (July 29, 2015), https://www.hongkongfp.com/2015/07/29/students-occupy-hku-council-meeting-overpro-vc-appointment-two-members-hospitalised/ [https://perma.cc/LJC9-XMYM].

242 See Convocation of the University of Hong Kong (HKU Convocation) Extraordinary General Meeting, U. H.K. Convocation (Sept. 1, 2015), http://www.convocation.hku.hk/doc/egm_voting_results_eng.pdf [https://perma.cc/8Z9K-DL2H].

243 See Kris Cheng, Johannes Chan Appointment to HKU Key Position Rejected, 12 Votes to 8, H.K. FREE PRESS (Sept. 29, 2015), https://www.hongkongfp.com/2015/09/29/johannes-chan-appointment-to-hku-keyposition-rejected/ [https://perma.cc/2M2F-8UUZ].

244 On May 31, 2016, the HKU Council appointed Terry Au, who had been serving as the Acting Pro-Vice-Chancellor for Academic Staffing and Resources since January 2016, to fill the position. See Email from HKU Alumni Office to HKU Alumni (May 31, 2016) (on file with authors).

245 Lau, supra note 236. 
with fellow Hong Kong-based Party mouthpiece Ta Kung Pao, released nearly 350 articles vilifying Chan, an average of more than one article a day. ${ }^{246}$ Both of these features suggest a coordinated campaign to target Chan.

More significantly, the "reasons" given by Council members for rejecting Chan strongly suggest that Chan was a target for political retribution. The Council officially gave no reasons for voting against Chan's appointment. However, the statements made by Council members against Chan were subsequently disclosed by whistle-blower and undergraduate Council representative Billy Fung, ${ }^{247}$ as well as in a series of leaked audio recordings of Council proceedings. ${ }^{248}$ The reasons given included Chan being a "nice guy" who held no doctoral degree-a rarity in Hong Kong legal academia, ${ }^{249}$ and that a Google Scholar search showed that Chan's research had only been searched-as opposed to cited- "four times in the last five years." "250 Most bizarrely of all, Council member Lo Chung-mau complained that Chan did not show sympathy after Lo fell during the altercation at the Council meeting in July 2015 . $^{251}$

The chain of events leading to the Council's vote against Chan has far-reaching implications for academic freedom within Hong Kong. Chan's stature within the Hong Kong legal community-as an eminent and engaged scholar of public law, and as the city's first, and so far only, Honorary Senior Counsel - should have been beyond question..$^{252}$ As a result, the vote against him-and

\footnotetext{
246 Ching, supra note 234.

247 See Karen Cheung, Student Leader Reveals HKU Council Members' Reasons for Blocking Johannes Chan Appointment, H.K. FreE Press (Sept. 30, 2015), https:/www.hongkongfp.com/2015/09/30/student-leader-reveals-hku-council-membersreasons-for-blocking-johannes-chan-appointment/ [https://perma.cc/8CXN-4336].

248 See Kris Cheng, More Leaked Audio Reveals HKU Council Member's Criticism of Pro-Democracy Scholar, H.K. FREE PRESS (Oct. 30, 2015), https://www.hongkongfp.com/2015/10/30/more-leaked-audio-reveals-hku-councilmembers-criticism-of-pro-democracy-scholar/ [https://perma.cc/8BB7-7JWN].

249 See Cheng, Explainer, supra note 230; see also Press Statement on 4 October 2015, FAC. L.U.. H.K. (Oct. 4, 2015), http://www.law.hku.hk/faculty/statement.php [https://perma.cc/S6K4-GGQF] (explaining, inter alia, the rarity of doctoral degrees in legal academia).

250 Cheng, Explainer, supra note 230.

251 Id.

252 Id.
} 
comments from Council members questioning his credentials and his probity - have been widely seen as part of a campaign of retribution against academics with pro-democracy views, especially at HKU..$^{253}$ In particular, Chan appears to have been singled out for vilification because he was Dean when Benny Tai began planning Occupy Central and did not prevent his colleague from serving as one of the chief organizers of the campaign. ${ }^{254}$

Chan's fate also reflects the impact of institutional shifts in Hong Kong's higher education landscape. Following reports both by the University Grants Committee and by the universities themselves recommending restructuring, ${ }^{255}$ university councilsincluding the HKU Council-have been restructured to include significantly greater lay participation. Yet the Chief Executive's role as ex officio Chancellor, and his power to appoint members to university councils, has remained unchanged. ${ }^{256}$ The result has been an increasingly hostile political environment for academics in Hong Kong. It is particularly worrying that the HKU Council reacted to revelations about its "reasons" for rejecting Chan by seeking to discredit whistle-blowers and suppress evidence, ${ }^{257}$ this

253 See, e.g., Hong Kong University Purge, Wall St. J. (Oct. 7, 2015), http://www.wsj.com/articles/hong-kong-university-purge-1444261236 [http://perma.cc/4N49-BZNY].

254 See Anthony Carty, What Exactly does 'Academic Freedom' mean to Johannes Chan and his Supporters?, S. CHINA MORNING POST (Oct. 7, 2015), http://www scmp.com/comment/insight-opinion/article/1864887/what-exactly-doesacademic-freedom-mean-johannes-chan-and [https://perma.cc/86GJ-GGC5] (op-ed by HKU Visiting Professor teaching at Tsinghua University).

255 See, e.g., Sutherland Report, supra note 154; see also Fit for Purpose, supra note 158.

256 See, e.g., University of Hong Kong Ordinance (2011) Cap. 1053, Laws of Hong Kong, $\quad$ \& $12(3), \quad$ Schedule, $\quad$ Statute XVIII, http://www.legislation.gov.hk/blis_pdf.nsf/3097404CFB27E75D482575EF00233639/\$FI LE/CAP_1053_e_b5.pdf [https://perma.cc/STF8-8LMK].

257 See Karen Cheung, Education Bureau Condemns Leaked HKU Council Tape as Police Investigation Deemed "Wasteful", H.K. FreE Press (Oct. 29, 2015), https://www.hongkongfp.com/2015/10/29/education-bureau-condemns-leaked-hkucouncil-tape-police-investigation-waste-of-resources-scholar/ [https://perma.cc/3VTUFJ8C] (stating that then-Council member Arthur Li referred to whistle-blower Billy Fung as a "liar"); see also Karen Cheung, Scope of HKU Injunction Narrowed to Only Cover Contents of Council Meetings Starting From June, H.K. FreE Press (Nov. 6, 2015), https://www.hongkongfp.com/2015/11/06/scope-of-hku-injunction-narrowed-to-onlycover-contents-of-council-meetings-starting-from-june/ [https://perma.cc/4XNJ-XPQ2] (stating that the Council also sought an injunction against the publication of recordings or documents of Council proceedings). 
provides a stark contrast to the public inquiry that the Council ordered during the Robert Chung affair in $2000 .^{258}$

Johannes Chan is not the only academic who has been affected by these developments. A number of academics at HKU, including the Vice Chancellor, have reported that their email accounts have been hacked. ${ }^{259}$ The clear purpose of the hacking is to allow the pro-Beijing press to search for evidence that might be used to tarnish the reputations of academics who are perceived as being "pro-democracy." For example, Benny Tai's HKU email account was hacked in 2014 and the pro-Beijing press subsequently used the emails to claim that Tai had accepted "anonymous" donations to HKU in 2013 and then "funneled" the money to political campaigns, such as Occupy Central. ${ }^{260}$ Benny Tai refuted these allegations, maintaining that he only introduced a donor to HKU (who was later revealed to be Reverend Chu) and that the money did not flow to Occupy Central but rather was given to three units on campus (the Law Faculty, the School of Humanities, and the Public Opinion Programme) to support a variety of research and education projects related to constitutional development. $^{261}$ In the opinion of Professor Chow Shew-Ping (the Pro Vice-Chancellor in charge of fundraising at the time), the donations themselves were not problematic in that they came from a reputable local citizen who wished to support on-going academic activities. $^{262}$

258 See Petersen, Lessons, supra note 21.

259 See Bryan Harris, Hackers Target Account of University of Hong Kong Vice Chancellor, S. CHINA MORNING POST (Apr. 26, 2015), http://www.scmp.com/news/hongkong/politics/article/1776567/hackers-target-email-account-university-hong-kong-vice [https://perma.cc/7SLE-DNPL].

260 See id.; see also Joyce $\mathrm{Ng}$, HKU Governing Body to Discuss Donations Accepted By Occupy Leader Benny Tai, S. ChinA Morning Post (May 22, 2015), http://www.scmp.com/news/hong-kong/politics/article/1806254/universitys-governingbody-discuss-donations-accepted-occupy [https://perma.cc/B5LB-M858] (stating that Tai was actually more of a middleman, serving as the initial recipient of checks that he delivered to HKU to fund conferences and research projects in three units on campus: the Faculty of Law, the School of Humanities, and the Public Opinion Programme).

261 See Joyce Ng \& Ng Kang-chung, HKU Split over Benny Tai Donations, S. China Morning Post (Mar. 26, 2015), http://www.scmp.com/news/hongkong/article/1747371/hku-split-over-whether-benny-tai-should-face-disciplinary-actionover [https://perma.cc/G7A8-Q7BQ].

262 See Response of Professor S. P. Chow to the Audit Committee Report, http://www.gs.hku.hk/report/SP-Chow.pdf [https://perma.cc/G7KF-FKHV] (noting that Tai was actually more of a middleman, serving as the initial recipient of checks that he 
Nonetheless, the Secretary for Education wrote to HKU's management and Council "repeatedly" to request that HKU conduct a thorough investigation into Tai; these letters have never been publicly disclosed but have been reported in the press and the local legislature and constitute a serious interference by the government in university governance. ${ }^{263}$ HKU's Council subsequently did order a full investigation by an Audit Committee. The investigation focused on: (1) the source of the donations, (2) how the donations were used, and (3) whether Benny Tai or other HKU employees violated any HKU regulations or policies. ${ }^{264}$

The Audit Committee's report (consisting of thirty pages plus an additional twenty pages of appendices) is very detailed. ${ }^{265}$ It concluded that the donor introduced by Benny Tai was reputable and that the donations funded legitimate academic activities (e.g. public forums on constitutional law, and referendums conducted by HKU's Opinion Poll Programme) ${ }^{266}$ It did identify a number of procedural problems but stressed that this was at least partly due to a lack of clear guidelines and procedures regarding the acceptance, utilization, and reporting of donations at HKU. ${ }^{267}$

With regard to Benny Tai, the most serious findings by the Audit Committee were: (1) that he re-assigned a research assistant from one project to other projects that were being funded by the same donor, a deviation from HKU guidelines; ${ }^{268}$ and (2) that he took too long (approximately six weeks) to reveal the identity of

delivered to HKU to fund conferences and research projects in three units on campus: the Faculty of Law, the School of Humanities, and the Public Opinion Programme).

263 See id.

264 See The University of Hong Kong Audit Committee, University of Hong Kong, Report to the Council on a Matter of Public Concern As to Certain Donations Received by the University, Parts I-II (Mar. 11, 2015), http://www.gs.hku.hk/report/AC-Report.pdf [https://perma.cc/79Y9-VBMY] [hereinafter Audit Committee Report].

265 Id.

$266 I d$.

267 Id. Part VI.

268 See id. IJ 56-64 (noting that the research assistant was originally appointed to assist Benny Tai in developing a new course in the School of Humanities. However, the course was postponed and she was assigned to assist in the POP polling projects and organizing conferences in the Faculty of Law). Although these projects were all funded by the same donor, the reassignment meant that one of the purposes of that donor (creation of the new course) was not achieved. The Audit Committee also concluded that the research assistant should have been re-appointed with a new letter of appointment rather than simply seconded to other projects supported by the donor. Id. 
the donor after HKU's Development and Alumni Affairs Office ("DAAO") requested the information. ${ }^{269}$ The Audit Committee concluded that this "seeming reluctance" by Tai fell short "of the standards of behavior expected of an academic introducing donors to the University." ${ }^{270}$ Tai maintains that he was not reluctant but needed to first secure permission from the donor (as the donor's original intention was to remain anonymous). ${ }^{271}$

The pro-Beijing press was not pleased by the report by the Audit Committee, accusing it of failing to "track down" all the donations and the connection to Occupy Central. ${ }^{272}$ In fact, the Audit Committee's report does note, very clearly, that the donor was Reverend Chu and the Committee was well aware that Chu was a leading participant in Occupy Central. ${ }^{273}$ But it considered $\mathrm{Chu}$ to be a reputable citizen and found no evidence that he attached any conditions to the donations that would impair HKU's impartiality when carrying out the research and education projects. $^{274}$ Instead, the Audit Committee identified procedural errors and found that HKU's guidelines were far too unclear, subject to many different interpretations, and insufficient to guide HKU employees. ${ }^{275}$

Nonetheless, HKU's Council ultimately decided to sanction Benny Tai by prohibiting him from accepting donations, managing researchers, or assuming a managerial position for three years. ${ }^{276}$ Some academics believe that these penalties were carefully crafted

\footnotetext{
269 See Letter from Audit Committee to Dr. C.H. Leong (Apr. 16, 2015), Letter of Elaborations Provided by the Audit Committee, Ig 1, 2(4), 7 , http://www.gs.hku.hk/report/Letter-of-elaborations.pdf [https://perma.cc/6358-DEGS] [hereinafter Audit Committee Letter] (noting that when the Audit Committee was asked by Council to summarize its extensive report and to "elaborate" on the actions of the individuals involved, this was one of only two paragraphs that criticized Benny Tai).

270 See Audit Committee Report, supra note 264, IJ 56-64.

271 See Audit Committee Letter, supra note 269, IJ 1-2, 7.

272 See China Daily, HKU Probe on Donation Inaccurate: Wen Wei Po, CHINA DAILY ASIA (Aug 13. 2015), http://www.chinadailyasia.com/hknews/201508/13/content_15303829.html [https://perma.cc/M2EK-CTEP].

273 See Audit Committee Report, supra note 264, I 2.

274 Id. Part VI.

275 Id.

276 See Benny Tai, Political Infiltration at the Hong Kong University Council, DEMOCRACY Chronicles (Jan. 2, 2016), https://democracychronicles.com/hong-konguniversity-council/ [https://perma.cc/4AWE-SMKW] (containing a copy of a letter, dated Oct. 21, 2015, from Benny Tai to the HKU Council).
} 
so as to satisfy the pro-Beijing forces while avoiding any substantial punishment. ${ }^{277}$ One interviewee described the penalties as a way to show Beijing that "blood" had been drawn from its enemies. In any event, Tai has strongly objected to the Council's decision, arguing that it was politically motivated and designed to punish him for his support, as a private citizen, for Occupy Central. Tai (who has taught Hong Kong administrative law for many years) has publicly accused the Council of a number of procedural errors in its decision-making process. ${ }^{278}$ In particular, he has pointed out that nothing in the University of Hong Kong Ordinance empowers the Council to impose disciplinary penalties on academic staff. ${ }^{279}$ Nor did the Council cite any "pre-existing rule or guideline that [Tai] breached or failed to comply with" or give him an opportunity to make representations in the Council meeting. ${ }^{280}$ Equally worrying is that HKU's Council took rather extreme measures to curtail public scrutiny of its decisions, not only holding closed-door meetings but even directing Tai to keep "confidential" the letter informing him of the penalties, except to the extent necessary to seek legal advice. ${ }^{281}$ This constitutes a clear attempt to prevent students, other faculty, and the general public from critiquing the Council's decision and the extent to which it may reflect government interference.

At least two other academics (Dr. Robert Chung, who directs the Opinion Poll Programme and Professor Daniel Chua, who was Dean of the School of Humanities when Reverend Chu donated money to that School) have been sanctioned by HKU's Council in a similar process. ${ }^{282}$ Interestingly, they also were directed to keep

277 See Joyce Ng, Occupy Central Co-Founder Benny Tai “Loves” His Employer The University of Hong Kong Too Much To Challenge It In Court, S. CHINA MoRning Post (Oct. 26, 2015, 11:24 PM), http://www.scmp.com/news/hong-kong/educationcommunity/article/1872558/occupy-central-co-founder-benny-tai-loves-his?page=all [https://perma.cc/E4LH-79ML].

278 See Tai, supra note 276.

279 Id.

280 Id.

281 Id.

282 See Joyce Ng \& Shirley Zhao, Occupy Central Founder Benny Tai Banned From Supervising Researchers for Three Years Following HKU Donation Scandal, S. CHINA MORning Post (Aug. 26, 2015), http://www.scmp.com/news/hong-kong/educationcommunity/article/1852595/university-hong-kong-scholars-face-disciplinary [https://perma.cc/LG9J-PSZS]. 
the formal notification of penalties confidential unless disclosure was for the purpose of obtaining legal advice. To his credit, Dr. Chung challenged the Council's attempt to gag him. In a letter responding to the Council (conspicuously labeled "not private" and "not confidential"), Dr. Chung complained that by "debarring individuals concerned from disclosing or discussing the content of your letter(s), the Council has effectively denied the public's right to know, and the rights of the individuals concerned to defend themselves."283

Ironically, the Council that took these steps was the product of "reforms" that were intended to ensure that HKU could be effectively governed. Of its twenty-four members, fifteen are required to be outsiders - neither students nor employees of HKU. ${ }^{284}$ Of those fifteen, seven-including the Council Chairare appointed by the Chief Executive, who is appointed by Beijing with no mandate from the people of Hong Kong. ${ }^{285}$ Six additional members are appointed by the Council itself, with the HKU Court-a separate advisory body-electing two further members. ${ }^{286}$ A minority of members are now drawn from the university itself, representing full-time teaching staff (4), full-time non-teaching staff (1), undergraduates (1) and postgraduates (1). ${ }^{287}$

The combination of majority outsider representation and the Chief Executive's continued powers of appointment has resulted in a university Council that is widely perceived to be politically pliant and pro-Beijing. Indeed, at the time of the vote against Johannes Chan's appointment, six out of twenty-two Council members were also members of the National People's Congress or the Chinese People's Political Consultative Committee-posts that signal close political ties with the central government. ${ }^{288}$ These six included former education minister Arthur Li, known for his highhanded administrative style and a long-standing grudge against

\footnotetext{
283 See Letter from Robert Chung to the Chairman of Hong Kong University's Council (Oct. 20, 2015) (copy on file with authors).

284 See University of Hong Kong Ordinance, (2003) Cap. 1053, Schedule, Statute XVIII (H.K.), http://www.elegislation.gov.hk/blis_pdf.nsf/3097404CFB27E75D482575EF00233639/\$ FILE/CAP_1053_e_b5.pdf [https://perma.cc/STF8-8LMK].

285 Id.

286 Id

287 Id.

288 See Cheng, Explainer, supra note 230.
} 
HKU. ${ }^{289}$

Despite the political fallout from the Johannes Chan saga, the Chief Executive has continued to pack university councils with members viewed as politically pliant. In October 2015 he appointed four pro-establishment figures to the Council of Lingnan University; ${ }^{290}$ the appointees included former Law Society president Junius Ho, who threatened to defund the Lingnan University Student Union over a performance of "Fuck the Police."291 Leung also appointed Arthur Li as Chair of the HKU Council on December 31, 2015, ${ }^{292}$ despite an overwhelmingly endorsed resolution by HKU's Convocation that Li was unfit for the office. ${ }^{293}$

In this atmosphere, it is not surprising that Hong Kong academics are far less confident in their freedoms than when interviewed a decade ago. In the past two years, academics from various institutions in Hong Kong have come forward and complained publicly of politically motivated harassment. These include Joseph Cheng Yu-shek (a former Chair Professor at City University of Hong Kong who believes that he has been targeted for his work with the Alliance for True Democracy), Dixon Ming Sing (an Associate Professor at Hong Kong University of Science and Technology, who has criticized China's repression of Falun Gong), and Liz Jackson (an Assistant Professor at HKU who perceived negative pressure from senior colleagues concerning her

\footnotetext{
289 See, e.g., Ip Kin-yuen, Why Arthur Li Should Not Be Appointed HKU Council Chairman, EJInSIGHT (Nov. 2, 2015), http://www.ejinsight.com/20151030-why-arthurli-should-not-be-appointed-hku-council-chairman/ [https://perma.cc/VUD3-EPGU] (containing an op-ed by the Convener of the Hong Kong University Alumni Concern Group).

290 Kris Cheng, Chief Executive Appoints Pro-Beijing Figures as Lingnan University Council Members, H.K. FreE PRESS (Oct. 9, 2015), https://www.hongkongfp.com/2015/10/09/chief-executive-appoints-pro-beijing-figuresas-lingnan-university-council-members/ [https://perma.cc/U295-VAK6].

291 Id.

292 Kris Cheng, CY Ally Arthur Li Appointed HKU Council Chairman Amid Strong Opposition, H.K. FREE PRESS (Dec. 31, 2015), https://www.hongkongfp.com/2015/12/31/cy-ally-arthur-li-appointed-hku-councilchairman-amid-strong-opposition/ [https://perma.cc/U78U-9HER].

293 University of Hong Kong Convocation, HKU Convocation Extraordinary General Meeting 29 November 2015 (Nov. 29, 2015), http://www.convocation.hku.hk/EGM/20151129/doc/final_results.pdf [https://perma.cc/VT5N-9BZ3].
} 
plans to edit a special issue of a journal on the 2014 prodemocracy protests). ${ }^{294}$ In confidential interviews, other academics in Hong Kong have reported that they fear (or in some cases know) that their email accounts have been hacked and that they have no confidence that their university will protect them if they are subjected to the type of smear campaigns that were waged against Johannes Chan and Benny Tai.

It is, of course, difficult for most academics to prove that they have been penalized or that they are being pressured. Very often, the message that one should avoid politically controversial projects is delivered in an "off the record" communication. For example, Professor Michael Davis was led to believe, from confidential statements by a senior administrator, that his public criticism of Beijing's policy towards Hong Kong may have adversely affected his application to extend his employment beyond the normal retirement age of sixty at the Chinese University of Hong Kong. ${ }^{295}$ Other academics have reported, in confidential interviews, that they perceive a heightened level of scrutiny of research and community service projects, particularly projects that may be funded by foundations from outside Hong Kong. ${ }^{296}$ Projects that might have been considered educational and a valuable community service before Occupy Central (such as the "Design Democracy" website established by the HKU's Centre for Comparative and Public Law) $)^{297}$ are now easy targets for the pro-China press, which

\footnotetext{
294 See David Matthews, Unsafe Harbour? Academic Freedom in Hong Kong, Times Higher Educ. Supplement (London) (Sept. 10, 2015), https://www.timeshighereducation.com/features/academic-freedom-in-hong-kongunsafe-harbour [https://perma.cc/6RTB-J869] (showing examples of their complaints); Simon Denyer, Is Hong Kong's Academic Freedom Under Chinese Attack? WASH. PosT (Mar. 13, 2015), https://www.washingtonpost.com/world/asia_pacific/is-hong-kongsacademic-freedom-under-chinese-attack/2015/03/12/8680fc60-e819-4ed0-9097-

04a9774cfd35_story.html [https://perma.cc/FKH8-8HAJ].

295 Interview with Michael Davis (Apr. 2016; cited with permission). Davis was a founding member of the Article 23 Concern Group and substantially involved in the public debate on Article 23 legislation. In 2011, after he was denied extension by the Chinese University of Hong Kong, Professor Davis took up an appointment as a Visiting Professor at HKU. See Academic Staff Professor Michael Davis, https://www.law.hku.hk/faculty/staff/davis_michael.php [https://perma.cc/AP9V-X6YR] (providing biography for Professor Michael Davis).

296 Summarized from a series of interviews with Hong Kong academics in 2015 and 2016, most of whom declined to be cited by name.

297 See Centre for Comparative and Public Law, Design Democracy: Promoting Constructive Dialog on the Future of Hong Kong's Political System,
} 
labels such activities as evidence of foreign influence and radicalization of Hong Kong's youth. It is not surprising that so many interviewees told us that they intend to "keep their heads down" during these difficult times. ${ }^{298}$ The authors have also spoken with foreign academics who are hesitant to accept positions at universities in Hong Kong due to their concerns that academic freedom has deteriorated. ${ }^{299}$ If this trend continues, the international reputation of Hong Kong's universities will be seriously undermined.

Dr. Peter Cunich (a longstanding academic in Hong Kong and the author of the leading book on the history of HKU) described the current atmosphere in vivid terms. He observed that threats to academic freedom are being discussed in Hong Kong more than at any time he could remember and that " $[\mathrm{t}]$ he degree to which HKU staff are free to express their political beliefs in 2015-16 (as opposed to 2014 when we all thought we had those rights protected) has been a topic of conversation among junior (untenured) staff in particular." ${ }^{300}$ Dr. Cunich also admitted that he has "advised [his] junior colleagues to keep a low profile and get on with their teaching and research."301 He drew a sharp distinction between 2002 and 2016, noting that "the Robert Chung Affair seemed to inspire us to fight back, whereas the current situation simply fills us all with despair." 302

\section{The Disapearing Booksellers}

The abduction of Hong Kong-based booksellers is perhaps the most potent symbol of Beijing's determination to bring Hong Kong to heel. ${ }^{303}$ On December 30, 2015, Lee Bo, a British national who worked for the Causeway Bay Books bookstore in Hong Kong, left for his warehouse to fulfill an unusually large

\footnotetext{
http://designdemocracy.hk/?lang=en [https://perma.cc/2G7H-JKM6] (last visited May $30,2016)$.

298 Summary of interviews of academics in 2015 and 2016.

299 Id.

$300 I d$.

301 Id.

302 Id.

303 See Nathan Vanderklippe, China Extends Reach to Take Hong Kong's Freedom of Speech Away, GlobE AND MAIL (TORONTO) (Jan. 21, 2016), http://www .theglobeandmail.com/news/world/china-extends-reach-to-take-hong-kongsfreedom-of-speech-away/article28332009/ [https://perma.cc/AQW6-KXYS].
} 
order. ${ }^{304}$ Causeway Bay Books was popular with certain mainland Chinese tourists because it sold books that would be embarrassing to the Chinese Communist Party and therefore banned in mainland China. ${ }^{305}$ Lee did not return; his was the fifth disappearance linked to Causeway Bay Books and its parent company Mighty Current Publishers. ${ }^{306}$

Lee's disappearance sent shock waves through Hong Kong. Like his colleague Gui Minhai-a Swedish national who had disappeared from Thailand weeks earlier-Lee had been born in China, but held a foreign passport. ${ }^{307}$ However, unlike Gui or their other colleagues, Lee had last been seen in Hong Kong. ${ }^{308}$ Eyewitnesses claim to have seen Lee bundled into a van outside of his warehouse in Chai Wan, presumably by state security agents from the mainland, who have no authority to operate within the territory of Hong Kong. ${ }^{309}$ For a Hong Kong public fearful of clandestine actions by the mainland security apparatus - ostensibly prohibited from operating in Hong Kong under Article 22 of the Basic Law-Lee's disappearance seemed to suggest the worst.

If Lee's apparent abduction had set alarm bells ringing in Hong Kong, his reappearance weeks later did nothing to calm the Hong Kong public. In a peculiar series of letters faxed from the mainland, Lee claimed that he had "voluntarily" returned to the mainland to assist in an investigation - an implausible assertion because his travel documents remained at home and the Hong Kong Immigration Department had no records of his departure. ${ }^{310}$ Meanwhile, Lee's colleague Gui also resurfaced - in a ten-minute interview on State-run television, in which he claimed he had turned himself in over a fatal drunk-driving accident twelve years

\footnotetext{
304 Id.

305 See id.

306 Id.

307 Id.

308 Id.

309 Kinling Lo, Waiting Game on Booksellers, STANDARD (H.K.) (Jan. 13, 2016), http://www .thestandard.com.hk/section-news.php?id=165119 [https://perma.cc/VV27-

310 See Regina Tan \& David Tweed, China Confirms Probe of Three Missing Hong Kong Booksellers, BLOOMBERG (Feb. 4, 2016), http://www.bloomberg.com/news/articles/2016-02-04/china-confirms-three-missinghong-kong-booksellers-under-probe [https://perma.cc/WL5P-BCMX].
} N7J5]. 
ago. ${ }^{311}$ Both Lee's letters and Gui's interview showed signs of coercion. $^{312}$ Only on February 4, 2016, did mainland Chinese authorities officially confirm that the remaining three Mighty Current staff were also in their custody. ${ }^{313}$ In March 2016, Lee Bo was permitted to return to Hong Kong, but he did not give a credible explanation of how he wound up in custody in mainland China. $^{314}$ Instead, he stated emphatically that he would never again publish books that are banned in mainland China. ${ }^{315}$ This statement alone provides clear evidence that Beijing has successfully employed fear and intimidation to stifle freedom of expression in Hong Kong.

The abduction of the "Causeway Bay Five," as they have become known, has raised serious questions about the state of Hong Kong's autonomy. A constitutional right to free speech in Hong Kong means nothing if an author or publisher can simply be kidnapped and taken across the border for prosecution. In a video that rapidly went viral, student activist Agnes Chow claimed that "Hong Kong is not Hong Kong anymore" 316 - a sentiment echoed by legislator Dennis Kwok, who told the New York Times that "this sort of stuff is just not supposed to happen in Hong Kong." 317

\footnotetext{
311 Vanderklippe, supra note 303.

312 Id.

313 Tan \& Tweed, supra note 310.

314 Ng Kang-chung \& Owen Fung, Bookseller Lam Wing-kee Reveals Explosive Details of his Mainland Detention, Claims Lee Po Told him he was "Taken Away From Hong Kong”, S. ChinA Morning Post (H.K.) (June 16, 2016), http://www.scmp.com/news/hong-kong/politics/article/1976489/bookseller-lam-wingkee-reveals-explosive-details-his [https://perma.cc/3S27-8TPR] (reporting that on June 16, 2016, Lee's colleague Lam Wing-kee - who had only returned to Hong Kong earlier in the week - confirmed that Lee had, by his own admission, been "taken away from Hong Kong").

315 Oliver Chou \& Phila Siu, I'll Never Publish Banned Books Again: Hong Kong Bookseller Lee Po Quits Book Trade Upon Return to City, S. CHINA MoRning PosT (H.K.) (Mar. $25 \quad$ 2016), http://www.scmp.com/news/hong-kong/lawcrime/article/1930513/ill-never-publish-banned-books-again-hong-kong-bookseller [https://perma.cc/T59D-ER95].

316 Koel Chu, Hong Kong is not Hong Kong Anymore, Scholarism's Agnes Chow Says, H.K. FreE PRESS (Jan. 4, 2016), https://www.hongkongfp.com/2016/01/04/hongkong-is-not-hong-kong-anymore-scholarisms-agnes-chow-says/ [https://perma.cc/A8FM-DN6E].

317 Michael Forsythe, Disappearance of 5 Tied to Publisher Prompts Broader Worries in Hong Kong, N.Y. TIMES (Jan. 4, 2016), http://www.nytimes.com/2016/01/05/world/asia/mighty-current-media-hong-kong-lee-
} 
Even political figures who have traditionally toed the Chinese Communist Party line have been moved to react. ${ }^{318}$ Wang Zhenmin, dean of Tsinghua Law School and legal affairs chief of the Liaison Office, told an academic conference that "[w]e are very concerned about the legal case ... like you," and that no Chinese law enforcement agencies could legally operate in Hong Kong. ${ }^{319}$

Even prior to the abduction of the Causeway Bay Five, Hong Kong's media environment had shown signs of becoming more restrictive. ${ }^{320}$ Over the preceding years, pro-Beijing tycoons have invested heavily in Hong Kong media companies, ${ }^{321}$ with Alibaba's acquisition of the English-language paper the South China Morning Post (albeit from another pro-Beijing owner) being the most recent example. ${ }^{322}$ The Apple Daily, a tabloid known for its staunch pro-democracy editorial stance, has suffered from companies' withdrawal of advertising, allegedly under pressure from Beijing. ${ }^{323}$ More significantly, the Liaison Office itself indirectly controls three major bookstore chains, as well as a plethora of print and online media outlets. ${ }^{324}$ In its 2015 annual report, the Hong Kong Journalists Association cited self-

bo.html [https://perma.cc/R2KV-KPZE].

318 See Clare Baldwin et al., Chinese Official Expresses Concern Over Missing Hong Kong Bookseller, REUTERS (Jan. 15, 2016), http://www.reuters.com/article/ushongkong-publisher-bookshops-idUSKCNOUT19O [https://perma.cc/ZU2R-GPXM].

319 Id.

$320 \mathrm{Id}$.

321 S.C. Yeung, Why Print Media in Hong Kong is Entering an Ice Age, EJInsight (July 17, 2015), http://www.ejinsight.com/20150717-why-print-media-hong-kong-isentering-ice-age/ [https://perma.cc/XT3G-Q3GB].

322 See, e.g., Bethany Allen-Ebrahimian et al., Can an Alibaba 'Morning Post' Aid China's Image Overseas?, CHINAFILE (Dec. 15, 2015), http://www.chinafile.com/node/22441 [https://perma.cc/LZU3-UHV5].

323 Enda Curran \& Chester Yung, Hong Kong Newspaper Says HSBC, Standard Chartered Pulled Ads, WALL ST. J. (June 16, 2014), http://www.wsj.com/articles/appledaily-says-hsbc-standard-chartered-pulled-ads-due-to-chinese-government-pressure1402923219 [https://perma.cc/X2L2-PAYM].

324 Ilaria Maria Sala, Creeping Censorship in Hong Kong: How China Controls Sale of Sensitive Books, GUARDIAN (Manchester) (May 18, 2015), http://www .theguardian.com/world/2015/may/19/censorship-in-hong-kong-how-chinacontrols-sale-of-sensitive-books [https://perma.cc/W44Y-C2CP]; Betsy Tse, Basic Law Violation Seen as LOCPG Tightens Grip on HK Publishers, EJInSIGHT (Apr. 9, 2015), http://www .ejinsight.com/20150409-basic-law-violation-seen-as-locpg-tightens-grip-onhk-publishers/ [https://perma.cc/QE2G-PLHT]. 
censorship as the biggest threat facing media workers in Hong Kong, alongside physical threats to journalists. ${ }^{325}$ Nonetheless, books banned on the Mainland-such as the political pot-boilers peddled by Causeway Bay Books - remained available in Hong Kong, a phenomenon which may have motivated the kidnappings. ${ }^{326}$ The renditions appear to have had the intended effect: shortly after Lee Bo's disappearance, bookstore chain Page One-one of the chains not controlled by the Liaison Officechose to remove all politically "sensitive" books from its shelves. ${ }^{327}$

More significantly, Lee Bo's abduction suggests that Mainland state security forces are operating within Hong Kong with new levels of brazenness. ${ }^{328}$ Although Article 22(1) of the Basic Law explicitly prohibits Mainland governmental entities from interfering in matters within Hong Kong's autonomy, democratic politicians and other critics of Beijing's rule remain subject to surveillance by Mainland security forces within Hong Kong. ${ }^{329}$ Religious organizations within Hong Kong have even been warned not to proselytize to visitors from the Mainland. ${ }^{330}$ Although there have been reports of previous abductions conducted within Hong Kong by State security, such incidents have largely targeted wayward Party members, rather than authors of salacious literature. $^{331}$ Lee's disappearance therefore represents a significant

\footnotetext{
325 Hong Kong Journalists Association, Journalists Caught Between Two Fires (July 2015), http://www.hkja.org.hk/site/portal/Site.aspx?id=A1-1367\&lang=en-US [https://perma.cc/4KXS-J5R2].

326 See Michael Sheridan, Leaked: China Plan to Hit Rebels Overseas, SUNDAY TIMES (LONDON) (Jan. 24, 2016), http://www.thesundaytimes.co.uk/sto/news/world_news/Asia/article1659622.ece [https://perma.cc/WW6A-7XXA] (describing a "Guangdong Action Plan").

327 Ilaria Maria Sala, Hong Kong Bookshops Pull Politically Sensitive Titles After Publishers Vanish, GuARDIAN (MANCHESTER) (Jan. 7, 2016), http://www .theguardian.com/world/2016/jan/07/hong-kong-bookshops-pull-politicallysensitive-titles-after-publishers-vanish [https://perma.cc/ZV3C-V5WT].

328 See David Lague et al., Special Report: How China Spies on Hong Kong's Democrats, REUTERS (Dec. 14, 2014), http://www.reuters.com/article/us-hong-kongsurveillance-special-report-idUSKBN0JT00120141215 [https://perma.cc/B6K4-MLVV].

329 Id.

330 Vivienne Zeng, Hong Kong Pastors Ordered to Stop Preaching to Mainlanders, H.K. FreE Press (July 6, 2015), https://www.hongkongfp.com/2015/07/06/hong-kongpastors-ordered-to-stop-preaching-to-mainlanders/ [https://perma.cc/XEG9-KADX].

331 Ching, supra note 28.
} 
escalation in Beijing's interference within Hong Kong.

If the specter of Mainland state security operating in Hong Kong - in flagrant breach of the Basic Law-was not sufficiently alarming for Hong Kongers, their government's reaction certainly was. Chief Executive C.Y. Leung initially called for Lee Bo to step forward and provide information; he went on to state that there was no evidence that state security had been involved in his disappearance. ${ }^{332}$ The police was criticized-by members of the force itself-for sending junior officers, rather than the Serious Cases squad, to investigate Lee's abduction. ${ }^{333}$ Neither the police-nor C.Y. Leung himself-publicly pressed Mainland authorities for answers, even though the latter were obliged to report cases involving Hong Kong residents in custody to their Hong Kong counterparts. ${ }^{334}$ Although we may never know what steps the Hong Kong government took behind the scenes, the absence of any such steps taken in public raises troubling questions about the local government's ability, or willingness, to protect Hong Kong's autonomy and the rights of its residents.

\section{Conclusion}

The developments analyzed in this article are deeply troubling and have caused great anxiety, not only for academics but for the broader Hong Kong community. The dystopian film "Ten Years," which depicted a Hong Kong in 2025 in which "youth guards" attacked a bookshop selling forbidden books, and in which a falseflag assassination was staged to ensure public support for national security legislation, resonated widely among the city's cinemagoers-outperforming even "Star Wars: The Force Awakens." 335 Although many residents continue to rely on

332 Lai Ying-kit \& Phila Siu, CY Leung on Hong Kong's Missing Booksellers: Mainland China Law Enforcement Actions 'Unacceptable,' S. CHINA MoRning PosT (H.K.) (Jan. 5, 2016), http://www.scmp.com/news/hong-kong/lawcrime/article/1897784/cy-leung-hong-kongs-missing-booksellers-mainland-china-law [https://perma.cc/GTQ4-WFBV].

333 Niall Fraser, Serving Hong Kong Police Officers Hit Out at Missing Booksellers Investigation, S. CHINA MORNING Post (H.K.) (Jan. 20, 2016), http://www.scmp.com/news/hong-kong/law-crime/article/1903505/serving-hong-kongpolice-officers-hit-out-missing [https://perma.cc/CB9F-CESB].

334 Id.

335 James Griffiths, “Ten Years:" Dark Vision of Hong Kong's Future Proves Surprise Box Office Hit, CNN (Jan. 21, 2016), http://www.cnn.com/2016/01/20/asia/hong-kong-ten-years-future/ 
peaceful means of protest, the Fishball Riots demonstrate that some Hong Kongers - in particular those affiliated with the "localist" political movements-have lost patience and are embracing more militant means of expressing their discontent. ${ }^{336}$

While the more violent means of protest seen in the Fishball Riots may not gain significant traction among Hong Kongers, other ideas espoused by localists have found fertile ground among university students. ${ }^{337}$ The HKU student-run magazine Undergrad, criticized by C.Y. Leung in 2015 for arguing that Hong Kongers were entitled to self-determination, ${ }^{338}$ published an issue in March 2016 advocating the territory's independence from China. $^{339}$ In the same month, Joshua Wong announced that he would disband Scholarism and set up a new political party to contest the legislative elections in September 2016, ${ }^{340}$ with the ultimate goal of seeking a referendum on Hong Kong's independence. ${ }^{341}$ The growing respectability of localist ideas and rhetoric-including the idea that Hong Kong should be independent from China altogether-reflect the extent to which public faith in "One Country, Two Systems" has been shaken. Unfortunately, the central and local governments have responded to the localist rhetoric by attempting to restrict discussion of independence in public schools ${ }^{342}$ and by prohibiting individuals

\footnotetext{
[https://perma.cc/PK9X-4FTD].

336 Levin, supra note 34.

337 Isabella Steger, Hong Kong Leader Singles Out College Magazine For Helping Cause "Anarchy", CHINA REAL TIME (Jan. 14, 2015), http://blogs.wsj.com/chinarealtime/2015/01/14/hong-kong-leader-singles-out-collegemagazine-for-helping-cause-anarchy/ [https://perma.cc/9RTH-2HW8].

338 Id.

339 Simon Lewis, Students at Hong Kong's Oldest University Are Calling for the City's Independence, TIME (Mar. 16, 2016), http://time.com/4260624/hong-konguniversity-students-independence-localism-separatists-undergrad/ [https://perma.cc/Z54G-VDJL].

340 Clifford Coonan, Joshua Wong Dissolves Hong Kong's Scholarism Group, IRISH TiMES (Mar. 21, 2016), http://www.irishtimes.com/news/world/asia-pacific/joshuawong-dissolves-hong-kong-s-scholarism-group-1.2581800 [https://perma.cc/NT5S4562].

341 Jennifer Pak, Hong Kong Protests: Joshua Wong to Launch Political Party, TELEGRAPH (London) (Feb. 18, 2016), http://www .telegraph.co.uk/news/worldnews/asia/hongkong/12163917/Hong-Kongprotests-Joshua-Wong-to-launch-political-party.html [https://perma.cc/4LZZ-4EQW].

342 See, e.g., Raymond Yeung and Ng Kang-Chung, Watch What You Say About
} 
who support independence from running for seats in Hong Kong's local legislature. ${ }^{343}$ These attempts to restrict peaceful advocacy almost certainly violate the ICCPR, as well as Hong Kong's Basic Law, and will only further damage public confidence in the "One Country, Two Systems" model. There is also a danger that Beijing will use the small independence movement as an excuse to renew its demand that Hong Kong implement Article 23 of the Basic Law by enacting local criminal laws to prohibit, inter alia, secession, sedition, and subversion against the central government. ${ }^{344}$ If the local legislature declined to do so, there is a possibility - although hopefully very remote-that the central government could invoke Article 18 of the Basic Law and try to apply selected national criminal laws in Hong Kong. ${ }^{345}$

Against this background, it would be an understatement to say that the reputation of Hong Kong - and of its universities - has suffered. Nonetheless, a declaration that "One Country, Two

Independence, CY Leung Warns Local Schools, S. ChINA MoRning Post (H.K.) (Aug 16, 2016), http://www.scmp.com/news/hong-kong/politics/article/2004621/watch-whatyou-say-about-hong-kong-independence-cy-leung [https://perma.cc/53HE-RJQB]; Earnest Kao, Hong Kong Teachers Warned They Could Be Struck Off for Separatist Talk in the Schools, S. ChINA Morning Post (H.K.) (Aug. 14, 2016), http://www scmp.com/news/hong-kong/politics/article/2003782/hong-kong-teacherswarned-they-could-be-struck-separatist [https://perma.cc/7F98-75W9].

343 See, e.g., Stuart Lau, New Legal Hoop for Hong Kong Legislative Council Candidates Muddies the Water for Upcoming Elections, S. CHINA MORNING PosT (H.K.) (July 22, 2016) http://www.scmp.com/news/hong-kong/politics/article/1993395/newlegal-hoop-hong-kong-legislative-council-candidates [https://perma.cc/Y7VD-LB9T] (noting that the ban was imposed administratively by the Electoral Affairs Commission and is currently being challenged in court); Jeffie Lam, Row Over Election Ban on Localists Escalates as Hong Kong Justice Minister's Explanation Backfires, S. CHINA Morning Post (H.K.) (Aug. 3, 2016), http://www.scmp.com/news/hongkong/politics/article/1998547/hong-kong-justice-secretary-defends-decision-bar-localist [https://perma.cc/KK6Z-ZVG6].

344 See Press Release, Mr. Rimsky Yuen, Secretary for Justice, Legis. Couns. Fin. Comm., Transcript of Remarks (Apr. 1, 2016), http://www.info.gov.hk/gia/general/201604/01/P201604010705.htm?utm_source=dlvr.it \&utm_medium=twitter [https://perma.cc/WW9L-KUY6] (showing that nonetheless, Secretary for Justice Rimsky Yuen appears to have taken the view that expressing secessionist views is per se illegal, albeit without identifying any substantive legal basis for that assertion).

345 Although Article 18 is confined to situations in which Hong Kong falls into war or turmoil that is beyond the control of the local government, the NPCSC holds the ultimate power of interpretation and Beijing has already shown its willingness to use this power to effectively amend sections of the Basic Law. 
Systems" has failed would be premature - and might become a self-fulfilling prophecy. On the contrary, Hong Kongers - and the international community - could do much to restore faith in Hong Kong and in the quality of its academic institutions.

As a signatory to the Joint Declaration, the United Kingdom has a legal right, if not an obligation, to monitor Chinese compliance with the Joint Declaration. Although earlier semiannual reports by the Foreign and Commonwealth Office have rightly been described as "anodyne," 346 the six-monthly report issued in February 2016 contained unusually trenchant criticism of China regarding Lee Bo, referring to his abduction as a "serious breach" of the Joint Declaration. ${ }^{347}$ In a similar vein, a joint statement issued by the United States on behalf of itself and eleven other countries, including the U.K., referred to the bookseller abductions as "a violation of the high degree of autonomy promised Hong Kong under its Basic Law." "348 Such statements, as well as international law mechanisms, such as the periodic reviews conducted by UN human rights treaty bodies, represent an important means of ensuring that Chinese commitments under the Joint Declaration - in particular those regarding critical speech and academic freedom - are upheld. It is crucial that the international community continues to remind China of its core obligations under the Joint Declaration.

Universities, academic associations, and individual academics around the world can also assist by paying close attention to Hong Kong and commenting upon any adverse developments in the territory. Hong Kong's public universities are well funded and the government wants them to be viewed as leaders in the global

346 Lord Patten of Barnes CH, former British Governor of Hong Kong, Oral Evidence: The UK's Relations with Hong Kong 30 years after the Joint Declaration (Nov. 4 , 2014) http://data.parliament.uk/writtenevidence/committeeevidence.svc/evidencedocument/fore ign-affairs-committee/the-uks-relations-with-hong-kong-30-years-after-the-jointdeclaration/oral/15097.html [https://perma.cc/76B3-FGP4].

347 Secretary of State for Foreign and Commonwealth Affairs, The Six-Monthly Report on Hong Kong 1 July to 31 December 2015 (Feb. 11, 2016), https://www.gov.uk/government/publications/six-monthly-report-on-hong-kong-july-todecember-2015 [https://perma.cc/FV29-G6HA].

348 Keith Harper, U.S. Ambassador to the HRC, Item 2: Joint Statement- Human Rights Situation in China (Mar. 10, 2016), https:/geneva.usmission.gov/2016/03/10/item-2-joint-statement-human-rights-situationin-china/ [https://perma.cc/YX8X-6ZRK]. 
market for higher education. ${ }^{349}$ It is important that the Hong Kong government also realize that decreases in academic freedom and educational autonomy will hurt the international reputation of Hong Kong's universities, making it more difficult for them to recruit international students and staff, as well as to establish exchange programs with foreign universities.

In this regard, it is encouraging that Scholars at Risk-a leading international network of universities supporting academic freedom-has taken a strong interest in Hong Kong, drawing attention to the rising threats to academic freedom in the territory. ${ }^{350}$

Substantive reforms to university governance are also needed if confidence in Hong Kong's universities is to be restored. The Chief Executive's role as Chancellor of publicly-funded universities - a major facilitator of political interference in the universities - is long overdue for abolition $^{351}$ and there is widespread support for this reform. ${ }^{352}$ Moreover, in our view, even the Hong Kong government would benefit if each university were permitted to select its own chancellor or president. The current situation creates unnecessary conflicts, as well as unrealistic expectations in Beijing regarding the Chief Executive's influence over academics and student organizations. It would be

\footnotetext{
349 The Government of the Hong Kong Special Administrative Region, Hong Kong: The Facts, Education (March 2016), http://www.gov.hk/en/about/abouthk/factsheets/docs/education.pdf [https://perma.cc/U3NT-TBSC].

350 See Scholars at Risk, NYU, http://scholarsatrisk.nyu.edu/ [https://perma.cc/WR9H-W387] (last visited May 30, 2016) (showing that for example, Scholars at Risk invited two academics from Hong Kong (Robert Chung and Alvin Y.H. Cheung) to participate in its 2016 Global Congress, helping to raise awareness of the threats to academic freedom in Hong Kong. Scholars at Risk also is considering holding an event on academic freedom in Hong Kong in order to demonstrate its support for students and academics in the territory and build solidarity.).

351 See Chris Patten, The Closing of the Academic Mind, ProjeCt Syndicate (Feb. 22, 2016), https://www.project-syndicate.org/commentary/academic-freedom-underthreat-by-chris-patten-2016-02 [https://perma.cc/25L8-YZ8M] (explaining that Chris Patten, the last British Governor of Hong Kong, claims that he suggested allowing the universities select their own chancellors before the handover, although this has been disputed.).

352 Academics Vote Against CE Influence on Councils, Radio TelEvision Hong KoNG (Mar. 24, 2016), http://news.rthk.hk/rthk/en/component/k2/125070720160324.htm [https://perma.cc/6AQW-6KQ7]. See also Petersen, Lessons, supra note 21 (proposing reforms following the Robert Chung affair).
} 
far better for both sides if the Chief Executive were no longer viewed - either by society or by Beijing - as even the titular head of Hong Kong's universities.

Similarly, the universities need to regain control over the appointment of the external members of their councils, so that universities are governed by individuals with genuine experience and expertise in the field, rather than by appointees of the Chief Executive who are primarily chosen for their loyalty to him. It is encouraging that the Newby Report on governance also appears to recognize that this is a serious problem that needs to be addressed. ${ }^{353}$ The University of Hong Kong has already announced that it will undertake a review of its governance structure, which will hopefully include an honest assessment of the centralization of power that occurred after the Sutherland Report. ${ }^{354}$

Of course, even if these reforms are adopted, the personal political activities of certain Hong Kong academics, on both sides of the political spectrum, are likely to be a source of flashpoints in the future. In addition to respecting and protecting academic freedom, Hong Kong's public universities have a duty to account for their resources and a legitimate interest in maintaining their political neutrality as institutions. These can be difficult goals to balance, even in functioning democracies. Many universities have struggled with whether to require academics to take leave when they engage in political activities that will require a major time commitment, such as running for office or managing a political campaign. ${ }^{355}$ One of Benny Tai's chief objections to the decision

\footnotetext{
353 Newby Report, supra note 116, at 20.

354 See KC Ng \& Shirley Zhao, Panel to Reform University of Hong Kong Governance to Meet Students and Staff in June, S. CHINA MoRning PosT (H.K.) (Mar. 24, 2016), http://www.scmp.com/news/hong-kong/educationcommunity/article/1930476/panel-reform-university-hong-kongs-governance [https://perma.cc/QWY3-R7PL] (reporting that the review panel will begin meeting with students and other stakeholders in June 2016); see also University of Hong Kong Press Release, HKU Council Establishes the Review Panel on University Governance and Appoints Members to Panel (Apr. 26, 2016), http://www.hku.hk/press/news_detail_14514.html [https://perma.cc/4GGL-YXRM].

355 See Kevin Dayton, Bill to Allow Legislators to Take Jobs at UH Goes to Senators, HonOlulu STAR AdVERTISER (Apr. 12, 2016),

http://www .staradvertiser.com/hawaii-news/bill-to-allow-legislators-to-take-jobs-at-uhgoes-to-senators/ [https://perma.cc/4SXX-99KE] (explaining that for example, faculty in the University of Hawaii, including part-time faculty, may not simultaneously serve in
} 
by HKU's Council to “discipline him" (regarding his management of a donation to HKU) is that the Council never cited any particular "pre-existing rule or guideline that [he had] breached or failed to comply with." 356 Tai's objection has merit: if a university genuinely believes that it has the authority to set rules or guidelines for academics who are politically active, then it should establish clear guidelines through a consultative process and then apply them in a transparent and politically neutral manner.

We suggest that Hong Kong academics develop and propose their own guidelines, which could expressly recognize and address the difference between politically sensitive research and commentary, on one hand, and personal political activities that may require major time commitments. Of course, both activities enjoy protection under the Basic Law and the ICCPR. But it would not be unreasonable for Hong Kong's universities to adopt politically neutral policies that seek to ensure that academics' personal political activities do not prevent them from fulfilling her professional responsibilities.

Although Hong Kong's universities face unique political pressures, the experiences of other universities - and the support of members of the academic community worldwide-will be indispensable in rebuilding confidence. The challenges posed to the "One Country, Two Systems" model by Beijing's increasing interference in Hong Kong-including those we describe in this article-cannot be overstated. Although Hong Kongers have mounted a robust defense of their city's autonomy, their efforts need greater international attention and support. Anything less might result in changes far more damaging - and permanent-to Hong Kong and its universities.

the Hawaii state legislature); see also Peter Schmidt, At Central Michigan University, Professors Fight To Protect Their Political Ambitions, 56 CHRONICLE OF Higher EduC. (July 22, 2010), http://chronicle.com/article/Central-Michigan-U-Professors/123676/ [https://perma.cc/65WG-3BDS] (describing objections by faculty to a university policy that requires them to seek permission before running for office).

356 See Tai, supra note 276. 